Article

\title{
Geochronology, Geochemistry, and Geodynamic Relationship of the Mafic Dykes and Granites in the Qianlishan Complex, South China
}

\author{
Zhi-Feng Yu ${ }^{1,2}{ }^{-}$, Qi-Ming Peng ${ }^{1,3}$, Zheng Zhao ${ }^{2, *}$, Ping-An Wang ${ }^{2}$, Ying Xia ${ }^{4}$, Yu-Qi Wang ${ }^{1,2}$ \\ and Hao Wang ${ }^{5}$ \\ 1 School of Earth Sciences and Resources, China University of Geosciences (Beijing), Beijing 100083, China; \\ yuzhifeng10@163.com (Z.-F.Y.); pqm@chinamining.org.cn (Q.-M.P.); wangyuqi39@163.com (Y.-Q.W.) \\ 2 MLR Key Laboratory of Metallogeny and Mineral Assessment, Institute of Mineral Resources, \\ Chinese Academy of Geological Sciences, Beijing 100037, China; wpand99@163.com \\ 3 China Mining Association, Beijing 100029, China \\ 4 College of Earth Sciences, Chengdu University of Technology, Chengdu 610059, China; woxiaying@126.com \\ 5 China Tungsten \& Hightech Materials Co., LTD, Zhuzhou 430200, China; wanghao05@minmetals.com \\ * Correspondence: zhaozheng@mail.cgs.gov.cn; Tel.: +86-186-1101-5998
}

Received: 3 November 2020; Accepted: 26 November 2020; Published: 29 November 2020

\begin{abstract}
The Qianlishan complex, located in Hunan Province of South China, is closely associated with intense W-dominated polymetallic mineralization. The Qianlishan complex is composed of three phases: the main-phase porphyritic and equigranular granites, granite porphyry, and mafic dykes. Geochronologically, the zircon U-Pb dating results show that the porphyritic and equigranular granites have ages of approximately 159 and $158 \mathrm{Ma}$, respectively, similar to those of mafic dykes (approximately $158 \mathrm{Ma}$ ), while the granite porphyry was formed later at approximately $145 \mathrm{Ma}$. Geochemically, the mafic dykes are characterized by calc-alkaline high-Mg andesite (HMA) with high $\mathrm{MgO}, \mathrm{TiO}_{2}, \mathrm{Mg \#}$, and $\mathrm{CA} / \mathrm{TH}$ index. They exhibit significantly depleted $\varepsilon \mathrm{Nd}(\mathrm{t})$ and $\varepsilon \mathrm{Hf}(\mathrm{t})$ with high $\mathrm{Ba} / \mathrm{La}, \mathrm{La} / \mathrm{Nb}$, and $(\mathrm{La} / \mathrm{Yb})_{\mathrm{N}}$, indicating that they formed from mixing melts of depleted asthenospheric mantle and metasomatized subcontinental lithospheric mantle (SCLM). The main-phase granites are peraluminous and are characterized by high $\mathrm{SiO}_{2}$, low $(\mathrm{La} / \mathrm{Yb})_{\mathrm{N}}$ ratios, and relative depletion in $\mathrm{Ba}, \mathrm{Sr}, \mathrm{Ti}$, and $\mathrm{Eu}$. They also display negative correlations between $\mathrm{La}, \mathrm{Ce}, \mathrm{Y}$, and $\mathrm{Rb}$ contents, suggesting that they are highly fractionated S-type granites. Furthermore, they show high $\varepsilon \mathrm{Nd}(\mathrm{t})$ and $\varepsilon \mathrm{Hf}(\mathrm{t}), \mathrm{CaO} / \mathrm{Na}_{2} \mathrm{O}$ ratios, $\mathrm{HREE}$, and $\mathrm{Y}$ contents, indicating that they were produced by parental melting of ancient basement mixed with mantle-derived components. In contrast, the granite porphyry shows A-type signature granites, with higher $\varepsilon \mathrm{Nd}(\mathrm{t})$ and $\varepsilon \mathrm{Hf}(\mathrm{t})$ and $\mathrm{CaO} / \mathrm{Na}_{2} \mathrm{O}$ ratios than the main-phase granites but similar $\mathrm{Zr} / \mathrm{Nb}$ and $\mathrm{Zr} / \mathrm{Hf}$ ratios to the mafic dykes, suggesting that they are the products of partial melting of a hybrid source with ancient basement and the mafic dykes. We thus infer that the slab roll-back led to generation of Qianlishan back-arc basalt and HMA and further triggered the formation of the Qianlishan granite.
\end{abstract}

Keywords: Qianlishan complex; highly fractionated granites; high-Mg andesite; South China

\section{Introduction}

South China is famous for its extensive and intensive Mesozoic W-dominated polymetallic mineralization [1], which is closely related to Mesozoic granites, and these granites were interpreted as the result of partial melting of crustal anatexis with possible contamination of country rocks [2-4]. The tectonic setting of the voluminous granitic activities is a subject of much debate, diversely interpreted as collision of the South China and Indochina Blocks [5-7] or subduction of the paleo-Pacific plate 
beneath the South China Plate [8-10]. These models suggest that the extensive magmatism generated bimodal volcanism [11], adakitic rocks [12], mafic and ultramafic rocks [13], and granitoids [7,14] within South China.

Recently, a growing dataset of Mesozoic granites in the Nanling region suggests that mantle-derived components might be involved in their sources [15-18]. These granites have relatively depleted $\varepsilon \mathrm{Nd}(\mathrm{t})$ (-6.7 to -3.3) with $\mathrm{Nd}$ model ages (e.g., 1.2-1.5 Ga [19]). Especially, the granites of 160 to $156 \mathrm{Ma}$ age in the Qianlishan complex display a wide range of $\varepsilon H f(t)$ (e.g., -9.25-+0.13), indicating a hybrid source of crust which involved a mantle-derived component [20]. Therefore, studying the mafic rocks in the Qianlishan complex to manifest the potential relationship between generation of these granites and mafic rocks is an appealing prospect.

The Qianlishan complex shows a close relationship with polymetallic mineralization of the giant Shizhuyuan W-Sn polymetallic deposit, as the ore-body occurs in the contact zone between the Qianlishan granites and the argillaceous banded limestone [21-23]. The mafic dykes are also exposed in the Qianlishan complex that hitherto lacked detailed age constraints. Previous studies were mainly focused on the mineralogy, petrology, and geochemistry of the Qianlishan granites [21-26]. Therefore, the study of geochemical and geochronological characteristics on Qianlishan mafic dykes and the Qianlishan granites may offer an opportunity to explain the mantle contribution of the granites and the possible deep mantle process that generated the mafic dykes and associated granites. In this study, we report whole rock geochemical and $\mathrm{Hf}-\mathrm{Nd}$ isotope data along with zircon $\mathrm{U}-\mathrm{Pb}$ geochronology data of granites and mafic dykes of the Qianlishan complex. These new data, in combination with previously published data for mafic dykes [20], allow for a new interpretation of the petrogenesis and geodynamic setting of the Qianlishan complex.

\section{Geological Setting}

South China is composed of the Yangtze Block in the northwest and the Cathaysia Block in the southeast (Figure 1), where they are separated by the northeastern part of Jiangshan-Shaoxing suture (J-S suture) [27]. The two blocks were amalgamated during the Neoproterozoic era [13,28]. The Nanling region includes southern Jiangxi, southern Hunan, northern Guangdong, and eastern Guangxi Provinces.

Strata exposed in the Nanling region mainly include weakly metamorphosed Precambrian sandstone. They are overlain by Paleozoic and lower Mesozoic mudstone or sandstone of shallow marine origin [18,29]. The Nanling region has experienced multiple tectonic events (e.g., Indosinian, 251-205 Ma and Yanshanian, 180-67 Ma), resulting in the formation of E-W strike-slip fault systems and N-E thrust fault systems controlling regional-scale magmatic activities (Figure 1). The sedimentary cover and basement have been subjected to strong intracontinental deformation under the influence of the Indosinian orogeny, forming Indosinian granites (251-205 Ma [14,18]). Subsequently, the tectonic environment of the Nanling region was dominated by the Yanshanian orogeny, generating abundant calc-alkaline granites [30,31]. Numerous W-Sn deposits were formed during these orogenic activities in the Nanling region (180-142 Ma [7,32]). Spatially, many of these deposits are associated with widespread Mesozoic granitic intrusions. Tungsten and tin mineralization usually occur along the contact zones between the granitic intrusions and the sedimentary strata and are hosted in both Devonian to Permian sedimentary rocks and in granitic rocks. The field relations suggest that W-Sn deposits in this region are essentially coeval with the host Mesozoic granites [33-35].

Moreover, numerous mafic rocks have been recorded in South China. Previous studies suggest natures of these mafic rocks. For example, the Devonian (approximately $365 \mathrm{Ma}$ ) and Carboniferous (approximately $340 \mathrm{Ma}$ ) basalts mainly derived from an enriched lithospheric mantle and OIB-type asthenosphere, respectively [36], Permian basalt and diabase (260-250 Ma) of South China [37,38], and Mesozoic mafic rocks are high-Mg andesite (HMA) (approximately $159 \mathrm{Ma}$ ) and are derived from an ancient metasomatized lithospheric mantle [39]. 


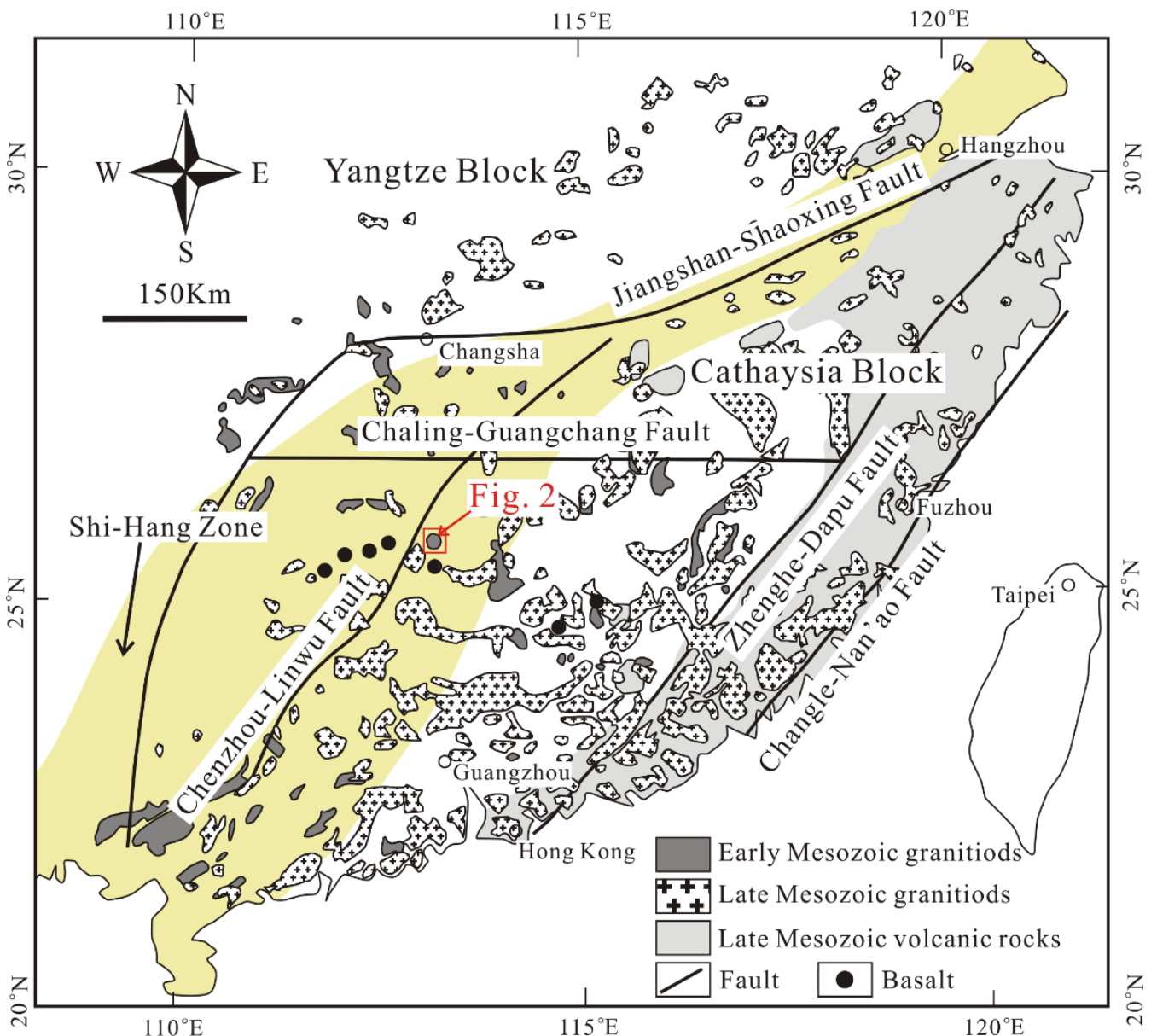

Figure 1. Geological map of the Nanling Region, South China modified from Chen et al. [40].

\section{Qianlishan Complex Petrography}

The Qianlishan complex is composed of the main-phase granites (porphyritic granites and equigranular granites), the granite porphyry, and the mafic dykes (Figure 2).

The porphyritic granite shows a white or light gray color (Figure 3a) and mainly consists of euhedral quartz $(30-35 \%, 0.5-3 \mathrm{~cm})$, megacrystic perthitic K-feldspar $(30-35 \%, 0.5-5 \mathrm{~cm})$, albite $(25-30 \%)$, and minor muscovite $(0-6 \%, 0.2-0.5 \mathrm{~mm}$, Figure $4 \mathrm{a})$. Accessory minerals include zircon, apatite, titanite, monazite, and ilmenite [40]. Pegmatite and greisen sometimes occur in the contact zone between these granites and the limestone. Most of the pegmatite form banded pegmatitic edges of $10-30 \mathrm{~cm}$ in the contact zone at the top of the granite (Figure 3a), and minor pegmatite is distributed into the granite forming pegmatitic schlieren (Figure 3b), which is composed of coarse-grained feldspar and quartz with associated aplite (Figure 3c). The equigranular granite mainly consists of K-feldspar ( $40 \%$, $0.5-3 \mathrm{~cm})$, quartz $(30 \%, 0.5-2 \mathrm{~cm})$, albite $(25 \%)$, and minor muscovite $(3 \%, 0.2-0.5 \mathrm{~mm})$, with accessory topaz, wolframite, and zircon (Figure $4 b, c)$. Skarn is formed in the contact zone of the main-phase granites and limestone. Massive $\mathrm{W}-\mathrm{Sn}$-Bi-Mo mineralization is present within skarn and is sometimes accompanied by cryptoexplosive breccia (Figure 3f). 


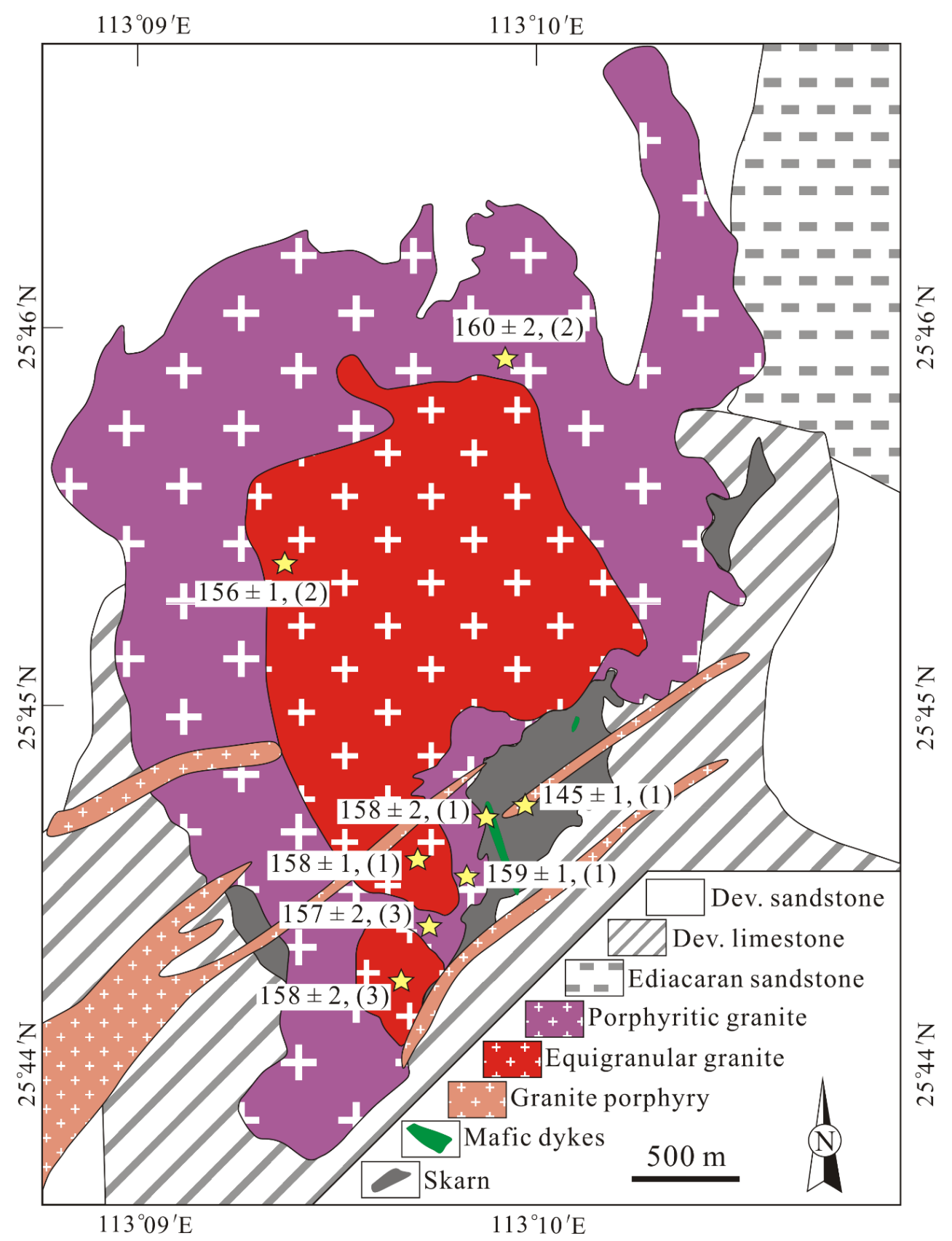

Figure 2. Sketch map of the Qianlishan granites modified from Chen et al. [40] and Chen et al. [20]. Data cited: (1) this paper, (2) Chen et al. [20], and (3) Chen et al. [40].

In the south of the Qianlishan granites, there are many NE-trending granite porphyry dykes that intruded into main-phase granite (Figures 2 and 3c). The dykes are approximately $1-4 \mathrm{~km}$ long and $0.2 \mathrm{~km}$ wide. Phenocrysts are mainly coarse-grained K-feldspar and quartz with minor plagioclase and grain sizes commonly over $3 \mathrm{~cm}$. The groundmass is a fine-grained granitic structure, and accessory minerals include zircon, apatite, titanite, fluorite, and pyrite (Figure 4d,e [40]). 

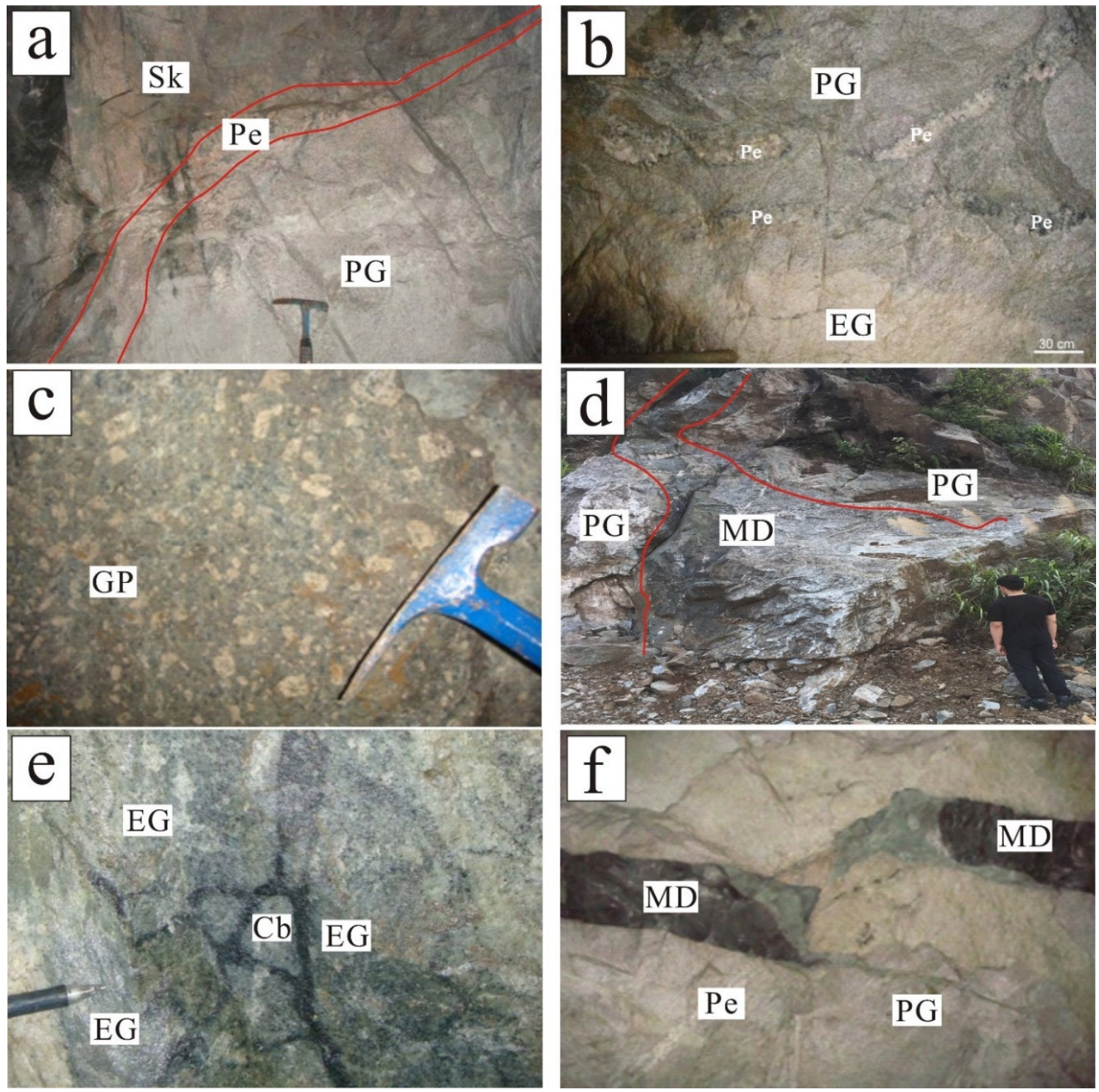

Figure 3. Photographs of the Qianlishan complex: (a) porphyritic granite and banded pegmatitic edge; (b) pegmatitic schlieren in porphyritic granite; (c) granite porphyry; (d) mafic dyke intruded into porphyritic granite; (e) cryptoexplosive breccia in equigranular granite; and (f) mafic dyke cut through the main-phase granite. Abbreviations: PG: porphyritic granite; EG: equigranular granite; GP: granite porphyry; MD: mafic dykes; Sk: skarn; Pe: pegmatite; and Cb: cryptoexplosive breccia.

The mafic dykes mostly intrude into granite or Devonian strata and are generally $20 \mathrm{~cm}$ to several meters wide (Figure $3 \mathrm{~d}, \mathrm{f})$. They are gabbroic and show an amygdaloidal structure consisting of phenocryst $(10 \%)$ and matrix $(90 \%)$. The phenocryst is composed of plagioclase and augite (Figure $4 \mathrm{f})$. The groundmass is slender tabular plagioclase (55\%), augite (25\%), amphibole $(10 \%)$, and minor biotite. 

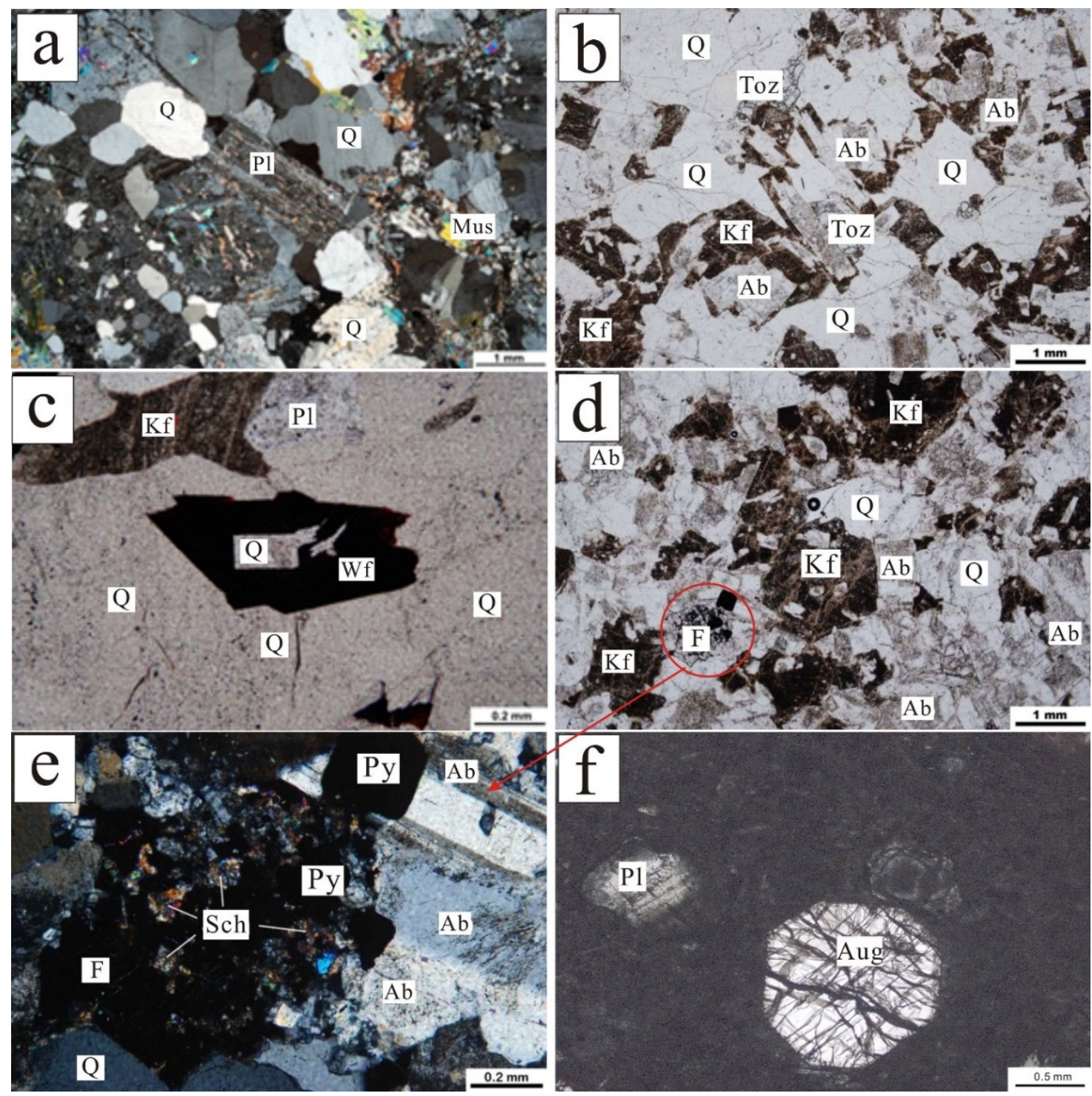

Figure 4. Microphotographs of rocks of the Qianlishan complex: (a) porphyritic granite; (b,c) equigranular granite; (d,e) granite porphyry; and (f) mafic dyke. Abbreviations: Pl: plagioclase; Q: Quartz; Mus: Muscovite; Kf: K-feldspar; Toz: topaz; Wf: Wolframite; F: Fluorite; Sch: scheelite; Py: pyrite; and Aug: augite.

\section{Analytical Methods}

\subsection{In Situ Zircon $\mathrm{U}-\mathrm{Pb}$ Isotopic Analyses}

Three granite samples (SZY1, SZY4, and SZY6) and one mafic dyke (SZY9) sample from the Qianlishan complex were collected for zircon U-Pb dating. Zircons were separated by conventional heavy-liquid and magnetic techniques at the Special Laboratory of the Geological Team in Langfang, Hebei Province, China. Cathodoluminescence (CL) images were taken using a HITACHI S-3000N scanning electron microscope fitted with a Gatan Chroma CL imaging system at the National Research Center for Geoanalysis (NRCG), Chinese Academy of Geological Sciences, Beijing, China.

$\mathrm{U}-\mathrm{Pb}$ zircon isotopic analyses were perform with use of LA-ICP-MS, using an Agilent 7500a ICP-MS equipped with a UP193SS laser ablation system at the MLR Key Laboratory of Metallogeny and Mineral Assessment, Institute of Mineral Resources, Chinese Academy of Geological Sciences, Beijing, China. A laser spot of $36 \mu \mathrm{m}$ was used for analysis, and a Harvard zircon 91500 standard with a recommended ${ }^{206} \mathrm{~Pb} /{ }^{238} \mathrm{U}$ age of $1065.4 \pm 0.6 \mathrm{Ma}$ was used for external standardization [41]; 
this standard was analyzed after every four unknown zircon analyses. Corrections for common $\mathrm{Pb}$ were made following the approach of Andersen [42], and data were processed using the GLITTER and ISOPLOT programs [43]. All reported ages are based on ${ }^{238} \mathrm{U} /{ }^{206} \mathrm{~Pb}$ calculated as weighted means with errors at the $95 \%$ confidence level. More details of the analytical procedure are provided in Black et al. [44].

\subsection{In Situ Zircon Hf Isotopic Analyses}

In situ zircon Hf-isotope analyses were performed at the same sites or in the same age domains (identified using $\mathrm{CL}$ images) as the zircon U-Pb analyses. The analyses were performed using a Neptune MC-ICP-MS equipped with a GeoLas 200M ArF excimer 193-nm laser ablation system at the same laboratory as the zircon U-Pb analyses. The detailed analytical technique is described in $\mathrm{Wu}$ et al. [45]. A $44-\mu \mathrm{m}$ laser spot size was selected during the ablation with a repetition rate of $8 \mathrm{~Hz}$ at $15 \mathrm{~J} / \mathrm{cm}^{2}$. ${ }^{175} \mathrm{Lu} /{ }^{176} \mathrm{Lu}$ of 0.02655 was used for elemental fractionation correction [46]. Isobaric interference of ${ }^{176} \mathrm{Yb}$ on ${ }^{176} \mathrm{Hf}$ was corrected using the mean fractionation index proposed by Iizuka and Hirata [47] and a ${ }^{176} \mathrm{Yb} /{ }^{172} \mathrm{Yb}$ ratio of 0.5886 [48]. Repeated measurements on the Mud Tank zircon standard yielded a mean ${ }^{176} \mathrm{Hf} /{ }^{177} \mathrm{Hf}$ ratio of $0.282506 \pm 11(2 \sigma, \mathrm{n}=177)$, which is consistent with the standard reference value of 0.282500 within error [45].

\subsection{Whole-Rock Geochemical Analyses}

Samples were collected for whole-rock geochemical analyses which were performed at the NRCG, Beijing, China. The major elements were determined by X-ray fluorescence (XRF model PW 4400), with analytical uncertainties ranging from $1 \%$ to $3 \%$. Loss on ignition was obtained using about $1 \mathrm{~g}$ of sample powder heated at $980{ }^{\circ} \mathrm{C}$ for $30 \mathrm{~min}$. The trace elements were analyzed by an Agilent $7500 \mathrm{ce}$ inductively coupled plasma mass spectrometer (ICP-MS). About $50 \mathrm{mg}$ of powder was dissolved for about 7 days at approximately $100{ }^{\circ} \mathrm{C}$ using $\mathrm{HF}-\mathrm{HNO}_{3}$ (10:1) mixtures in screw-top Teflon beakers, followed by evaporation to dryness. The material was dissolved in $7 \mathrm{~N} \mathrm{HNO}_{3}$ and taken to incipient dryness again and then was redissolved in $2 \% \mathrm{HNO}_{3}$ to a sample/solution weight ratio of 1:1000. The analyses of the international standards (GSR-3) were in good agreement with the recommended values [49]. Trace and rare earth elements were analyzed with analytical uncertainties of $10 \%$ for elements with abundances $<10 \mathrm{ppm}$ and approximately $5 \%$ for those with $>10 \mathrm{ppm}$. The detailed analytical procedures were similar to those described by Luo et al. [50].

$\mathrm{Nd}$ isotopic compositions of the 11 samples (eight granites and three mafic dykes) were measured using an MAT262 mass spectrometer at Nanjing Focus Technology Co. Ltd. For calculation of $\varepsilon \mathrm{Nd}(\mathrm{t})$ values, $\mathrm{Nd}$ model ages and adopted parameters were as follows: decay constant for ${ }^{147} \mathrm{Sm}$ was $6.54 \times 10^{-12}$ per year; ${ }^{147} \mathrm{Sm} /{ }^{144} \mathrm{Nd}$ ratio of chondritic uniform reservoir (CHUR) was 0.1967; ${ }^{143} \mathrm{Nd} /{ }^{144} \mathrm{Nd}$ ratio of CHUR was $0.512638 ;{ }^{147} \mathrm{Sm} /{ }^{144} \mathrm{Nd}$ and ${ }^{143} \mathrm{Nd} /{ }^{144} \mathrm{Nd}$ ratios for depleted mantle (DM) were 0.2136 and 0.513151 , respectively; and a ${ }^{147} \mathrm{Sm} /{ }^{144} \mathrm{Nd}$ ratio of 0.12 was used for average continental crust. The measurement procedures were the same as described by Zhu et al. [51].

\section{Results}

\subsection{Zircon $U-P b$ Geochronology}

Three granite samples from the Qianlishan granites and one mafic dyke sample were selected for zircon $\mathrm{U}-\mathrm{Pb}$ dating (sampling positions are shown in Figure 2), and the data are listed in Supplementary Table S1.

Zircons from the main-phase granites are typically euhedral to subhedral with varying crystal length $(80-150 \mu \mathrm{m})$ and an aspect ratio of 1:1 to 3:1 (Figure 5a,b). They show clearly homogeneous oscillatory zoning patterns, indicating that they are magmatic in origin [52]. The concentrations of Th and $\mathrm{U}$ are $92-600$ and $178-2353$ ppm, respectively, and the Th/U ratios are $0.27-0.65$ (Supplementary Table S1). Analyses for 20 zircons from SZY1 samples yielded zircon $\mathrm{U}-\mathrm{Pb}$ weighted mean ages of $158.9 \pm 1.1 \mathrm{Ma}$ 
$(\mathrm{MSWD}=0.45)$ and 15 zircons from the SZY4 sample yielded zircon U-Pb weighted mean ages of $157.8 \pm 1.4 \mathrm{Ma}(\mathrm{MSWD}=0.77)($ Figure $5 \mathrm{a}, \mathrm{b})$.
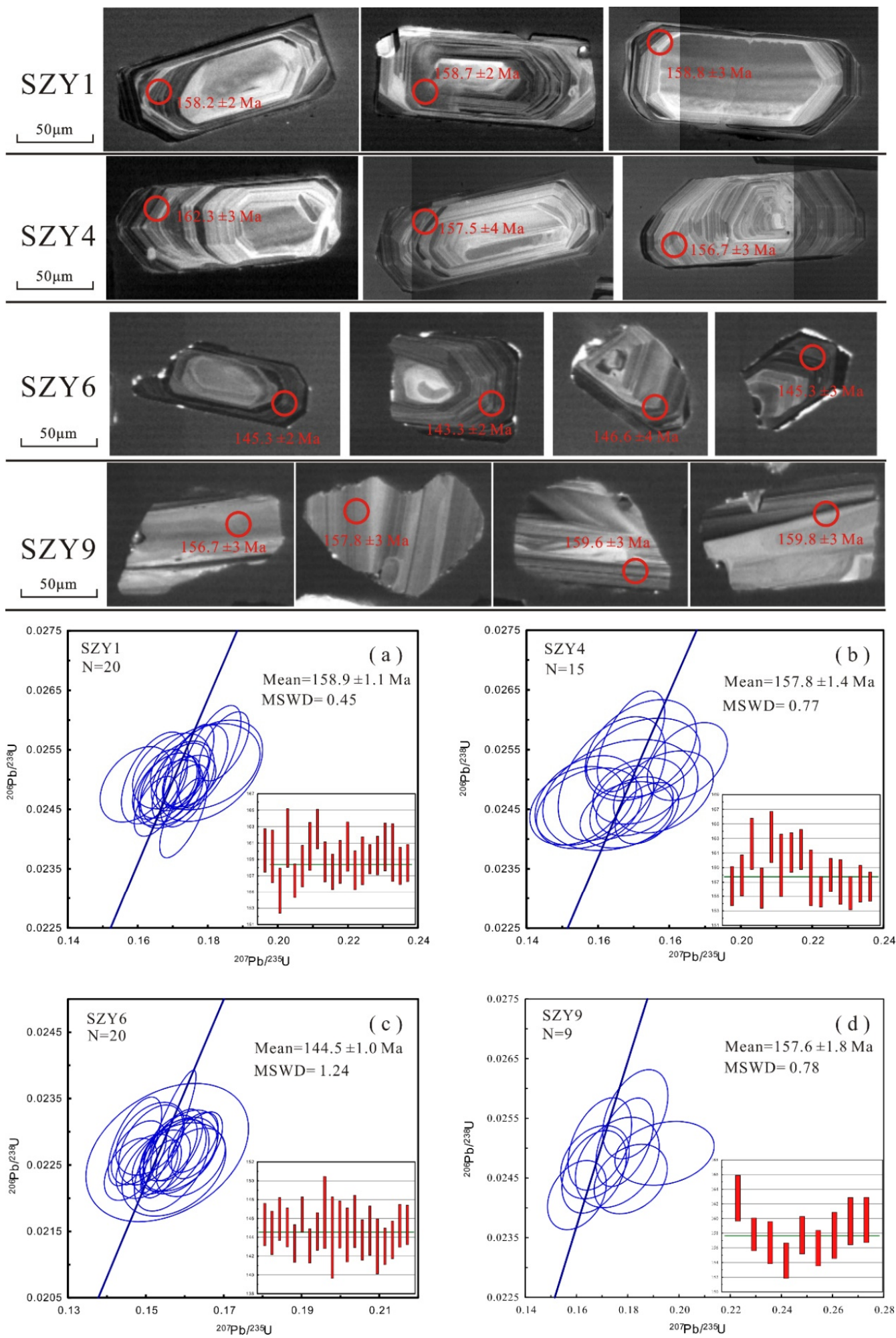

Figure 5. U-Pb concordia diagrams of zircon data and representative cathodoluminescence images of zircons from the Qianlishan complex: (a) main-phase porphyritic granites; (b) main-phase equigranular granites; (c) granite porphyry; and (d) mafic dykes. MSWD—mean square of weighted deviates. 
Zircons from the granite porphyry (SZY6) can be distinguished from those of the main-phase granites by their smaller sizes $(60-120 \mu \mathrm{m})$ and show weak luminescence in CL images (Figure 5c). The concentrations of Th and $U$ are 121-986 and 238-1773 ppm, and the Th/U ratios are 0.33-0.60 (Supplementary Table S1). Analyses for 20 zircons from SZY6 samples yielded zircon U-Pb weighted mean ages of $144.5 \pm 1.0 \mathrm{Ma}$ (MSWD $=1.24$ ).

Zircons of SZY9 samples are from the mafic dykes. They are mostly up to 50-100 $\mu \mathrm{m}$ in size and have length to width ratios of between 1:1 and 2:1 (Figure 5d). Most zircons are clear, simple prismatic crystals without obvious zoning on CL images. The concentrations of Th and U are 100-282 and 137-428 ppm, and the Th/U ratios are 0.51-0.98 (Supplementary Table S1). Analyses for nine zircons from SZY9 samples yielded zircon U-Pb weighted mean ages of 157.6 $\pm 1.8 \mathrm{Ma}(\mathrm{MSWD}=0.78$ ).

\subsection{Zircon Hf Isotopes}

The zircon Hf isotopic data are listed in Supplementary Table S2. The Hf isotopic analyses for 20 zircon grains from the main-phase porphyritic granites yielded $\varepsilon \mathrm{Hf}(\mathrm{t})$ values from -8.3 to +0.7 . Analyses of 12 zircons from the main-phase equigranular granites resulted in $\varepsilon \mathrm{Hf}(\mathrm{t})$ values in the range of -7.4 to -0.3 . Analyses of 20 zircons from the granite porphyry yielded $\varepsilon H f(t)$ values in the range of -6.3 to +3.9 , higher than those of the main-phase granites. Analyses of eight zircons from the mafic dykes gave $\varepsilon \mathrm{Hf}(\mathrm{t})$ values in the range of -4.4 to +4.3 (Figure 6).

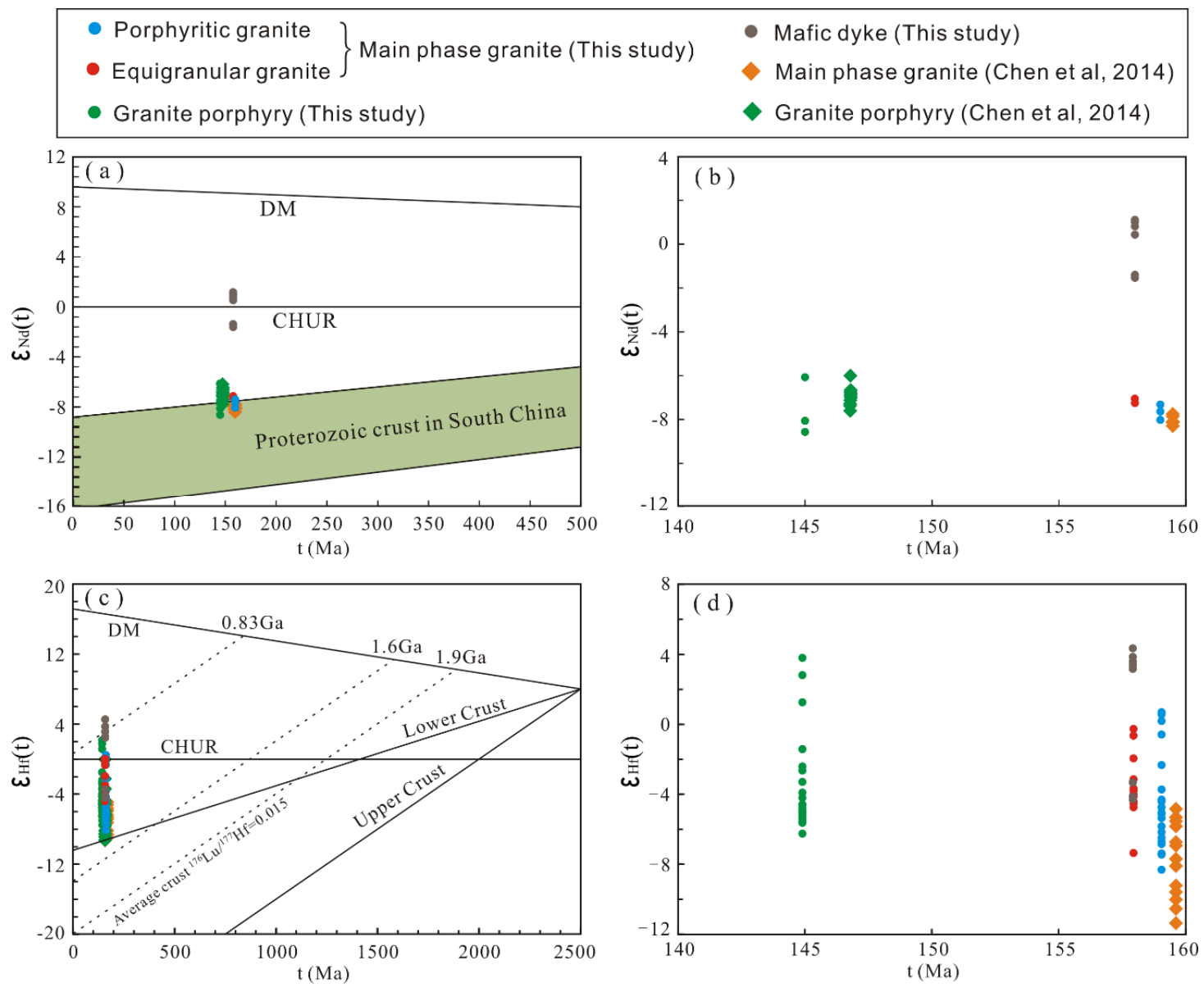

Figure 6. Plots of $\varepsilon N d(t)$ versus $t(\mathbf{a}, \mathbf{b})$ and $\varepsilon H f(t)$ versus $t$ diagrams $(\mathbf{c}, \mathbf{d})$ for the granites and mafic dykes of the Qianlishan complex: the $\varepsilon \mathrm{Nd}$ isotopic evolution fields for Proterozoic crust in South China are cited from Shen et al. [53]. Data cited from Chen et al. [20]. 


\subsection{Whole-Rock Geochemical Results}

The rocks have varying loss on ignition (LOI) contents that range from 0.84 to $4.80 \mathrm{wt} . \%$. These results, in combination with field and petrographic observations, suggest that these rocks underwent varying degrees of alteration. However, large ion lithophile elements (LILE; e.g., Rb and La) are correlated with high field strength element (HFSE; e.g., Th and $\mathrm{Nb}$ ) in these samples, indicating that these elements were not disturbed significantly by alteration. The whole-rock geochemical data are listed in Supplementary Table S3.

The main-phase porphyritic granites are characterized by high $\mathrm{SiO}_{2}(72.16-75.63$ wt.\%), low $\mathrm{MgO}\left(0.09-0.32\right.$ wt.\%), and $\mathrm{P}_{2} \mathrm{O}_{5}(0.02-0.05$ wt.\%). In addition, these samples are high- $\mathrm{K}$ highly fractionated calc-alkalic series $\left(\mathrm{K}_{2} \mathrm{O}=5.68-6.41 \mathrm{wt} . \%\right)$ and belong to peraluminous granites as indicated by the aluminum saturation index $(\mathrm{A} / \mathrm{CNK}=1.31-1.38$; Figure 7$)$. These granites show flat rare earth element $(\mathrm{REE})$ patterns with $(\mathrm{La} / \mathrm{Yb})_{\mathrm{N}}=1.21-1.36$ and are enriched in LILE, exhibiting significantly negative $\mathrm{Sr}, \mathrm{Ba}, \mathrm{Eu}$, and high field strength element (HFSE) anomalies (Figure 8). The main-phase equigranular granites display similar geochemical characteristics to the porphyritic granites, including $\mathrm{SiO}_{2}$ (74.67-75.45 wt.\%), $\mathrm{MgO}(0.01-0.02 \mathrm{wt} . \%), \mathrm{P}_{2} \mathrm{O}_{5}(0.02-0.03 \mathrm{wt} . \%)$, $\mathrm{K}_{2} \mathrm{O}$ (3.33-4.85 wt.\%), and A/CNK (1.43-1.93) of major elements. They also belong to high-K highly fractionated calc-alkalic and peraluminous granites (Figure 7). Moreover, They also show flat REE patterns with $(\mathrm{La} / \mathrm{Yb})_{\mathrm{N}}=1.67-1.87$ and display more significantly negative $\mathrm{Sr}$, Ba, Eu, and HFSE anomalies (Figure 8). In summary, the main-phase granites of the Qianlishan complex are peraluminous high-K highly fractionated calc-alkalic granites.
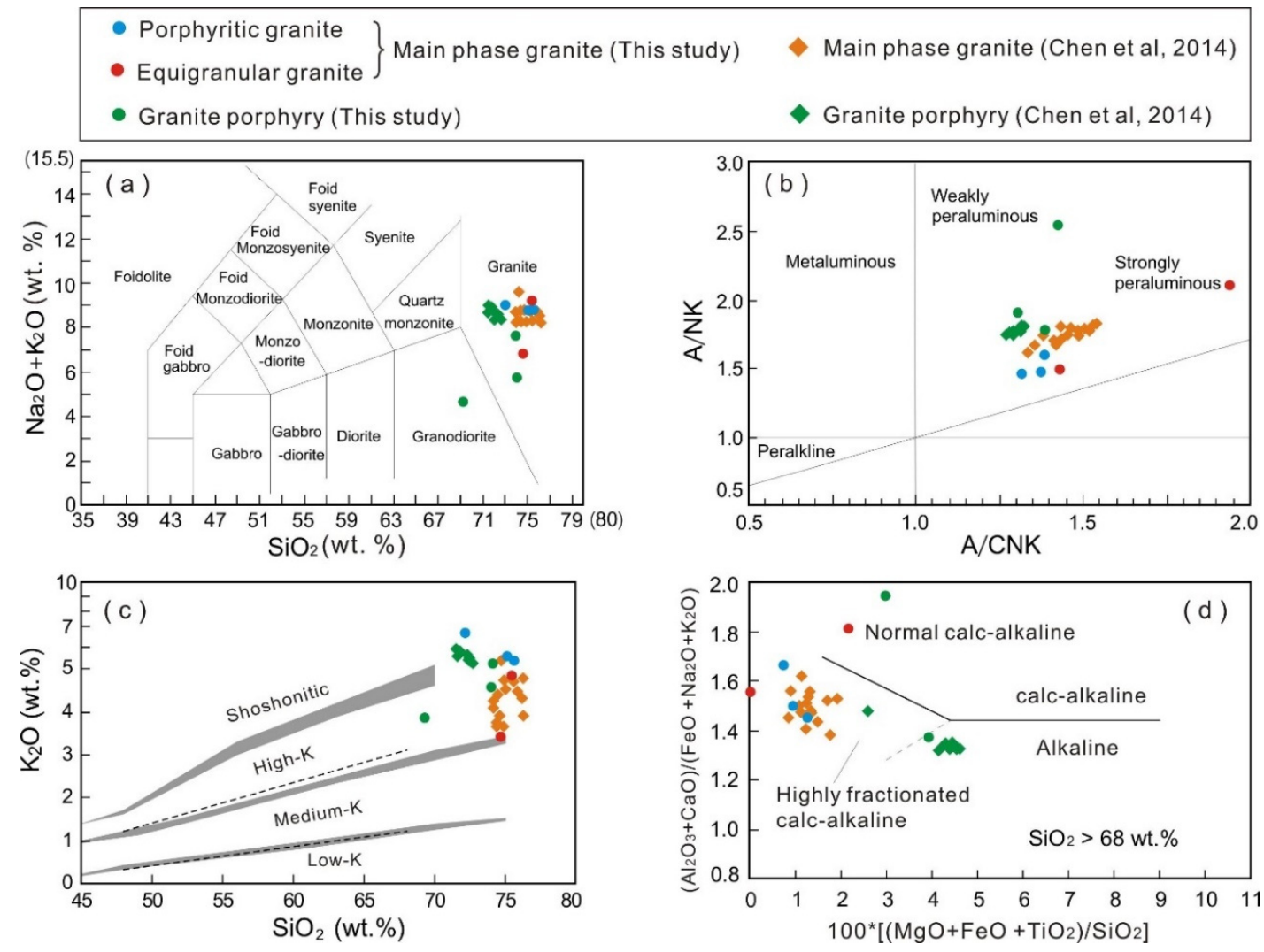

Figure 7. Geochemical classification of the Qianlishan granites: (a) total alkali vs. silica (TAS) diagram for classification [54]; (b) diagram of A/NK vs. A/CNK [55], A/NK = molar ratio of $\left[\mathrm{Al}_{2} \mathrm{O}_{3} /\left(\mathrm{Na}_{2} \mathrm{O}+\right.\right.$ $\left.\left.\mathrm{K}_{2} \mathrm{O}\right)\right], \mathrm{A} / \mathrm{CNK}=$ molar ratio of $\left[\mathrm{Al}_{2} \mathrm{O}_{3} /\left(\mathrm{CaO}+\mathrm{Na}_{2} \mathrm{O}+\mathrm{K}_{2} \mathrm{O}\right)\right] ;(\mathbf{c}) \mathrm{K}_{2} \mathrm{O}$ vs. $\mathrm{SiO}_{2}$ diagram [56]; and (d) $\left(\mathrm{Al}_{2} \mathrm{O}_{3}+\mathrm{CaO}\right) /\left(\mathrm{FeO}+\mathrm{Na}_{2} \mathrm{O}+\mathrm{K}_{2} \mathrm{O}\right)$ vs. $100 *\left[\left(\mathrm{MgO}+\mathrm{FeO}+\mathrm{TiO}_{2}\right) / \mathrm{SiO}_{2}\right]$ classification diagram [57] Data cited from Chen et al. [20]. 
The granite porphyry exhibits similar geochemical characteristics to major elements as main-phase granites, suggesting that it is high-K and peraluminous granite (Figure 7). However, they show lower $\mathrm{Na}_{2} \mathrm{O}+\mathrm{K}_{2} \mathrm{O}\left(4.59-7.53\right.$ wt.\%) contents and higher $\mathrm{MgO}+\mathrm{FeO}+\mathrm{TiO}_{2}(2.21-16.25$ wt.\%) contents than those in main-phase granite, suggesting that they belong to Alkalic granite but not the highly fractionated granite (Figure 7). In addition, the geochemical characteristics of trace elements of the granite porphyry are enriched in LREE, with $(\mathrm{La} / \mathrm{Yb})_{\mathrm{N}}=2.85-16.10$, and show indistinct $\mathrm{Sr}, \mathrm{Ba}, \mathrm{Eu}$, and HFSE anomalies compared to the main-phase granites (Figure 8). Therefore, the granite porphyry in Qianlishan granites consist of peraluminous high-Kalkalic granites.

The mafic dykes are characterized by high $\mathrm{MgO}$ (8.28-9.13 wt.\%), $\mathrm{Cr}$ (527.09-791.36 ppm), and Ni (113.98-224.98 ppm) contents and $\mathrm{Mg} \#(>60)$, which shows affinity to primitive andesite [58]. They are enriched in LREE with $(\mathrm{La} / \mathrm{Yb})_{\mathrm{N}}=8.43-13.28$ (Figure 8). They exhibit relative depletion of $\mathrm{Sr}$ and HFSE (e.g., $\mathrm{Nb}, \mathrm{Zr}$, and Ti; Figure 8), with high $\mathrm{MgO}>8$ wt. $\%$, $\mathrm{TiO}_{2}>0.5$ wt.\%, and $\mathrm{Mg \#}>60$. Therefore, the mafic dykes at Qianlishan belong to calc-alkaline high-Mg andesite (HMA; [59]).

The Nd isotope composition of 11 samples was analyzed (Supplementary Table S4). Whole-rock $\varepsilon \mathrm{Nd}(\mathrm{t})$ values of the main-phase granites and the granite porphyry are -8.04 to -7.10 and -8.58 to -8.08 , respectively. The values of the mafic dykes are -2.08 to 0.73 .
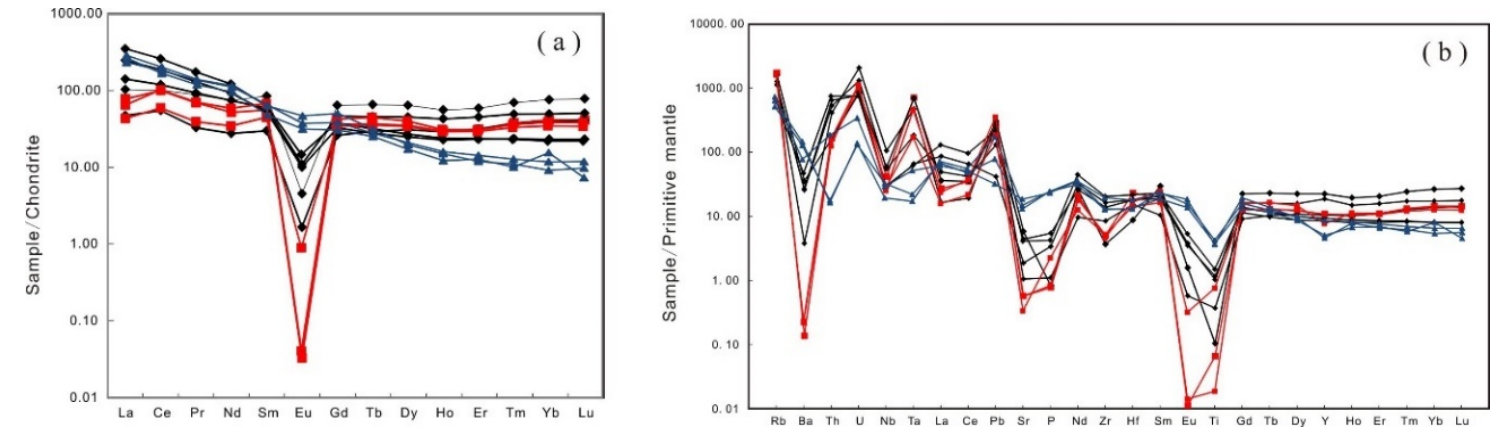

Figure 8. (a) Chondrite-normalized rare earth element (REE) patterns of main-phase granites, granite porphyry, and mafic dykes of Qianlishan and (b) primitive mantle-normalized trace element diagrams for main-phase granites, granite porphyry, and mafic dykes of Qianlishan (main-phase granites in black, granite porphyry in red, and mafic dykes in blue): the values of chondrite and primitive mantle are from [60].

\section{Discussion}

\subsection{Ages of Qianlishan Granites and Mafic Dykes}

In this study, the main-phase porphyritic and equigranular granites yielded zircon $\mathrm{U}-\mathrm{Pb}$ ages of $158.9 \pm 1.1$ and $157.8 \pm 1.4 \mathrm{Ma}$, respectively. These ages are higher than the ages of $153 \pm 2$ and $152 \pm 2$ Ma obtained by the method of SHRIMP (Supplementary Table S5; [24,61]). They do, however, show concordance with the mineralization age of $159.8 \pm 2.9$ Ma by molybdenite Re-Os isochron date [62]. As the mineralization is closely related to the Qianlishan main-phase granites, we thus conclude that the age in this study is accurate and that the difference may be due to multiple magmatic pulses because of different sample locations [40]. The granite porphyry exhibits a zircon U-Pb age of $144.5 \pm 1.0 \mathrm{Ma}$. The mafic dykes sample displays a zircon U-Pb age of $157.6 \pm 1.8 \mathrm{Ma}$. Although we observed that the mafic dykes intrude into the main-phase granite (Figure 3e), their zircon $\mathrm{U}-\mathrm{Pb}$ age within error (1.14\%) cannot be distinguished by the method of LA-ICP-MS [63], and the age results indicate that they might be generated contemporaneously. However, we observed that the mafic dykes are cutting through the main-phase granites in the field (Figure 3f), so the mafic dykes are later than the main-phase granites. Therefore, the geochronological characteristics of the Qianlishan complex suggest that the main-phase granites and mafic dykes have contemporaneous emplacement ages and are significantly older than the granite porphyry. 


\subsection{Genesis Type of the Qianlishan Complex}

The main-phase granites are characterized by high $\mathrm{SiO}_{2}$ (72.16-75.63 wt.\%); differentiation index values; low $(\mathrm{La} / \mathrm{Yb})_{\mathrm{N}}$ ratios (1.21-1.87); and distinct $\mathrm{Ba}, \mathrm{Sr}, \mathrm{Ti}$, and Eu depletions (Figure 8), suggesting an affinity of A-type granites (Figure 9a-c [64]). However, it is difficult to identify the genetic type of such highly fractionated granites because the compositions of such rocks tend to be close to the near minimum-temperature melt [65]. The low abundances of HFSE ( $\mathrm{Nb}=17.5-74.9 \mathrm{ppm}$ and $\mathrm{Y}=34.2-102.2 \mathrm{ppm}$, Supplementary Table S3) especially indicate that these samples cannot be simply considered A-type granites, which are characterized by high abundances of HFSE (>350 ppm [64,66]). It has been well accepted that the content of REE in I-type and S-type granitic melts could be used as an effective indicator to distinguish the genetic type of granite $[67,68]$. This is because highly fractionated S-type granites generally have low $\mathrm{La}, \mathrm{Ce}$, and $\mathrm{Y}$ contents and have a negative correlation of $\mathrm{Rb}$ (Figure 9; [67]). The peraluminous and highly fractionated signatures in combination with the negative arrays involving REEs vs. Rb (Figure 9d-f), suggest an S-type affinity for all of the main phase Qianlishan granites [69]. Moreover, in $\mathrm{Eu} / \mathrm{Eu}^{*}$ vs. $\mathrm{SiO}_{2}$ and $\mathrm{Zr} / \mathrm{Hf}$ vs. $\mathrm{Nb} / \mathrm{Ta}$ plots (Figure 10), these samples reveal an increasing degrees of magma differentiation, which causes the rise in content of $\mathrm{Ga}$ and further results in the abnormally high $10,000^{*} \mathrm{Ga} / \mathrm{Al}$ ratios, which show A-type affinity in Figure $9 b, c$.
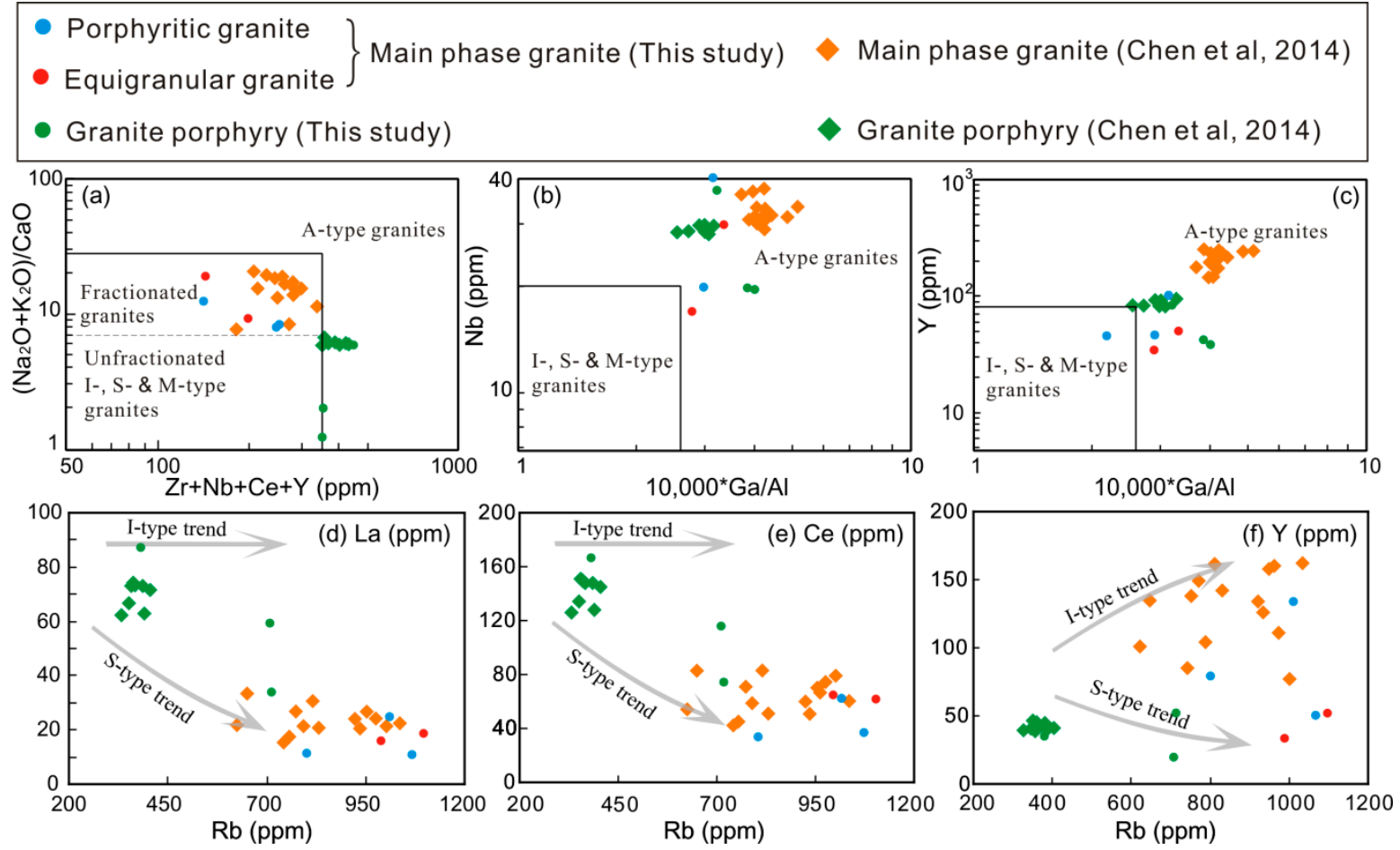

Figure 9. Selected plots of trace element concentrations from I-, S-, and A-type granitoids: (a) $\left(\mathrm{Na}_{2} \mathrm{O}\right.$ $\left.+\mathrm{K}_{2} \mathrm{O}\right) / \mathrm{CaO}$ vs. $\mathrm{Zr}+\mathrm{Nb}+\mathrm{Ce}+\mathrm{Y},(\mathbf{b}) \mathrm{Nb}$ vs. $10,000^{*} \mathrm{Ga} / \mathrm{Al}$, and (c) $\mathrm{Y}$ vs. $10,000^{*} \mathrm{Ga} / \mathrm{Al}$ classification diagrams [64]. (d-f) Selected plots for distinguishing I-type and S-type magmas indicate that the granite samples are most likely fractionated from S-type magmas [67]. Data cited from Chen et al. [20].

In contrast, the geochemical characteristics of the granite porphyry samples show high ratios of $10,000^{*} \mathrm{Ga} / \mathrm{Al}$, high content of $\mathrm{Nb}+\mathrm{Ce}+\mathrm{Y}+\mathrm{Zr}(>350 \mathrm{ppm})$ and are enriched in $\mathrm{Nb}, \mathrm{Ce}, \mathrm{Y}$, and $\mathrm{Ga}$. Therefore, they can be seen in the A-type granite zone in the discrimination diagrams of A-type granite (Figure 9a-c), consistent with Chen et al. [20] and Chen et al. [40] but different from the views on S-type granites of Guo et al. [24]. In fact, the granite porphyry showed extremely low $\mathrm{P}_{2} \mathrm{O}_{5}$ content $(<0.25 \%)$, obviously differing from the abundance of $\mathrm{P}_{2} \mathrm{O}_{5}$ found in fractionated S-type granite [67].

Thus, the granite porphyry is A-type granite. 


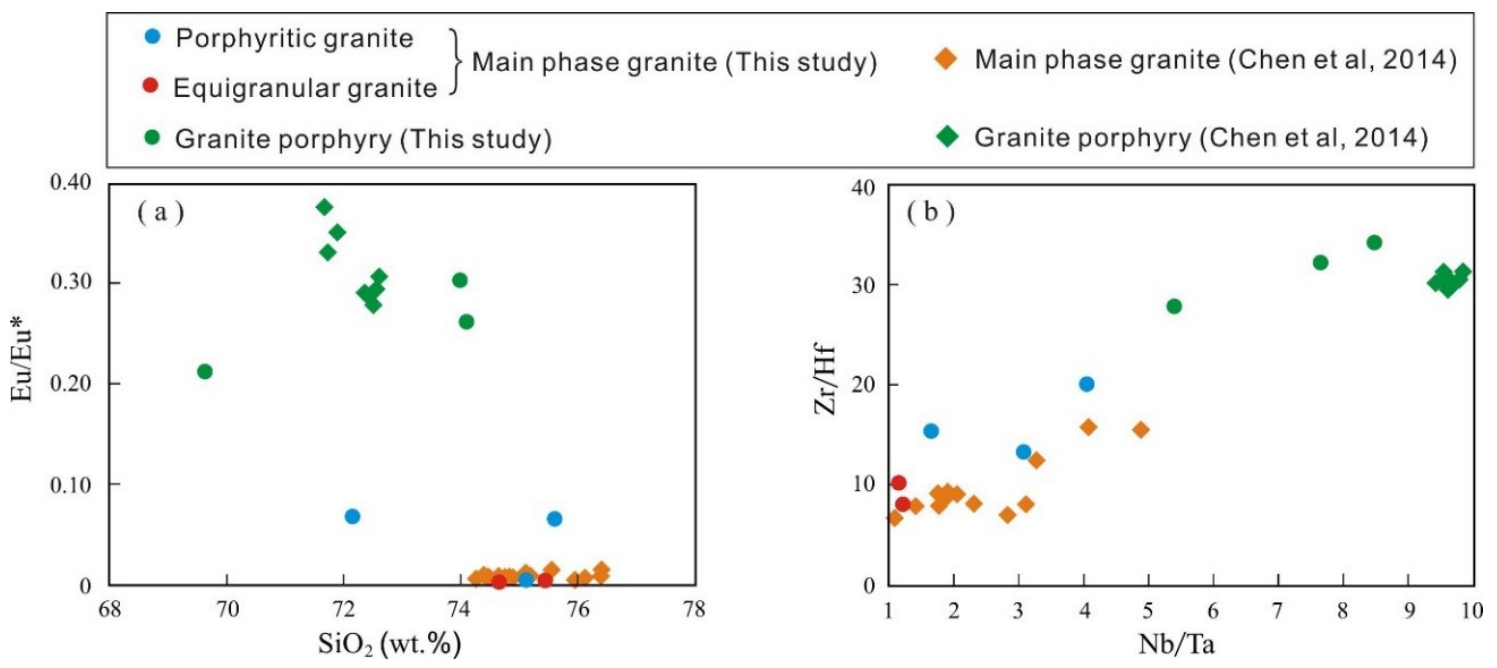

Figure 10. Diagrams of (a) $\mathrm{SiO}_{2}$ vs. $\mathrm{Eu} / \mathrm{Eu}^{*}$ and (b) $\mathrm{Nb} / \mathrm{Ta}$ vs. $\mathrm{Zr} / \mathrm{Hf}$ in which the common range of granites is as reported by Jahn et al. [70]. Data cited from Chen et al. [20].

The mafic dykes are represented by sub-alkaline andesite in the $\mathrm{SiO}_{2}$ vs. $\mathrm{Zr} / \mathrm{TiO}_{2} * 10,000$ and $\mathrm{SiO}_{2}$ vs. $\mathrm{Nb} / \mathrm{Y}$ diagram (Figure 11a,c). Furthermore, the CA/TH index of the mafic dykes is $>1$, and the high Th content indicates that they are calc-alkaline (Figure 11b,d; [71]). The calc-alkaline andesite has high $\mathrm{MgO}>8 \mathrm{wt} . \%, \mathrm{TiO}_{2}>0.5 \mathrm{wt} . \%$, and $\mathrm{Mg \#}>60$, showing geochemical affinity to Setouchi high-Mg andesite (HMA; Figure 11e,f [72]). This HMA exhibits slightly enriched LREE and depleted Nb-Ta-Ti (Figure 8). In addition, it is characterized by low $\mathrm{SiO}_{2}$ (51.1-54.6 wt.\%), $\mathrm{Sr}$ (270-383 ppm), and $\mathrm{Sr} / \mathrm{Y}$ ratios (12.0-14.9) with high $\mathrm{Y}(20.6-28.7 \mathrm{ppm}), \mathrm{Yb}(2.61-3.88 \mathrm{ppm})$, and $\mathrm{K}_{2} \mathrm{O} / \mathrm{Na}_{2} \mathrm{O}$. Such characteristics are distinct from those of typical adakites [73] but similar to Sanukitic HMA (Figure 11f and Figure 15b; [72]).

\subsection{The Relationship between Qianlishan Mafic Dykes and Granites}

In situ zircon Hf isotopic analysis is an effective tool in determining the nature of magma sources and the mixing process during the formation of magmas [78]. Though the main-phase granites are highly evolved S-type granites and they preserve little evidence of the composition of the parental magmas and show different $\mathrm{Nd}$ isotopes and HFSE ratios (e.g., $\mathrm{Zr} / \mathrm{Nb}$ and $\mathrm{Zr} / \mathrm{Hf}$ in Figure 12) from the contemporaneous mafic dykes, the isotopic results still provide us a chance to explore the nature of their origin [79]. The diagram of age versus $\varepsilon N d(t)$ shows low and homogeneous $\varepsilon N d(t)$ values of the main-phase granites plotted in the zone of the Precambrian crust of the South China Block (SCB) and mantle (Figure $6 \mathrm{a}, \mathrm{b})$. In contrast, the zircon $\mathrm{Hf}$ isotopes exhibit a much wider range of $\varepsilon \mathrm{Hf}(\mathrm{t})$ values from -8.3 to 0.7 (Figure $6 \mathrm{c}, \mathrm{d}$ ), indicating that the mantle-derived component was indeed involved in their genesis. Therefore, the main-phase granites may be the products of parental melting of ancient basement with highly negative $\varepsilon \mathrm{Hf}(\mathrm{t})$ values mixed with mantle-derived components with $\varepsilon \mathrm{Hf}(\mathrm{t})$ values around zero. However, compared to the Qianlishan mafic dykes, the main-phase granite samples display high HREE $(\mathrm{Yb}=6.12-13.1 \mathrm{ppm})$ and $\mathrm{Y}(34.2-102 \mathrm{ppm})$ contents and flat HREE patterns, precluding a residual phase within the crustal source [80]. Moreover, these samples have significant negative anomalies of Eu and $\mathrm{Sr}$, enrichment in LILE, and the trace element patterns requiring partial melting of source rocks within the stability field of plagioclase [73]. Hence, they should have a relatively shallow source (approximately $30 \mathrm{~km}$ ). Therefore, we propose that the main-phase granites were derived from partial melting of crustal rocks at a shallow depth caused by underplating of the basaltic magmas and mixed parts of a lateral underplating magma. 


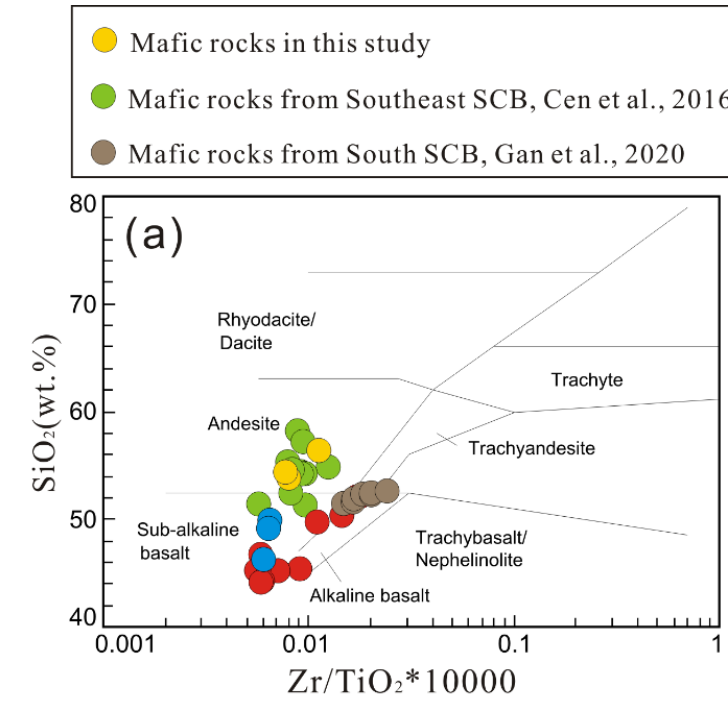

Mafic rocks of Qianlishan, Chen et al., 2014

Mafic rocks from North SCB, Zhao et al., 2010
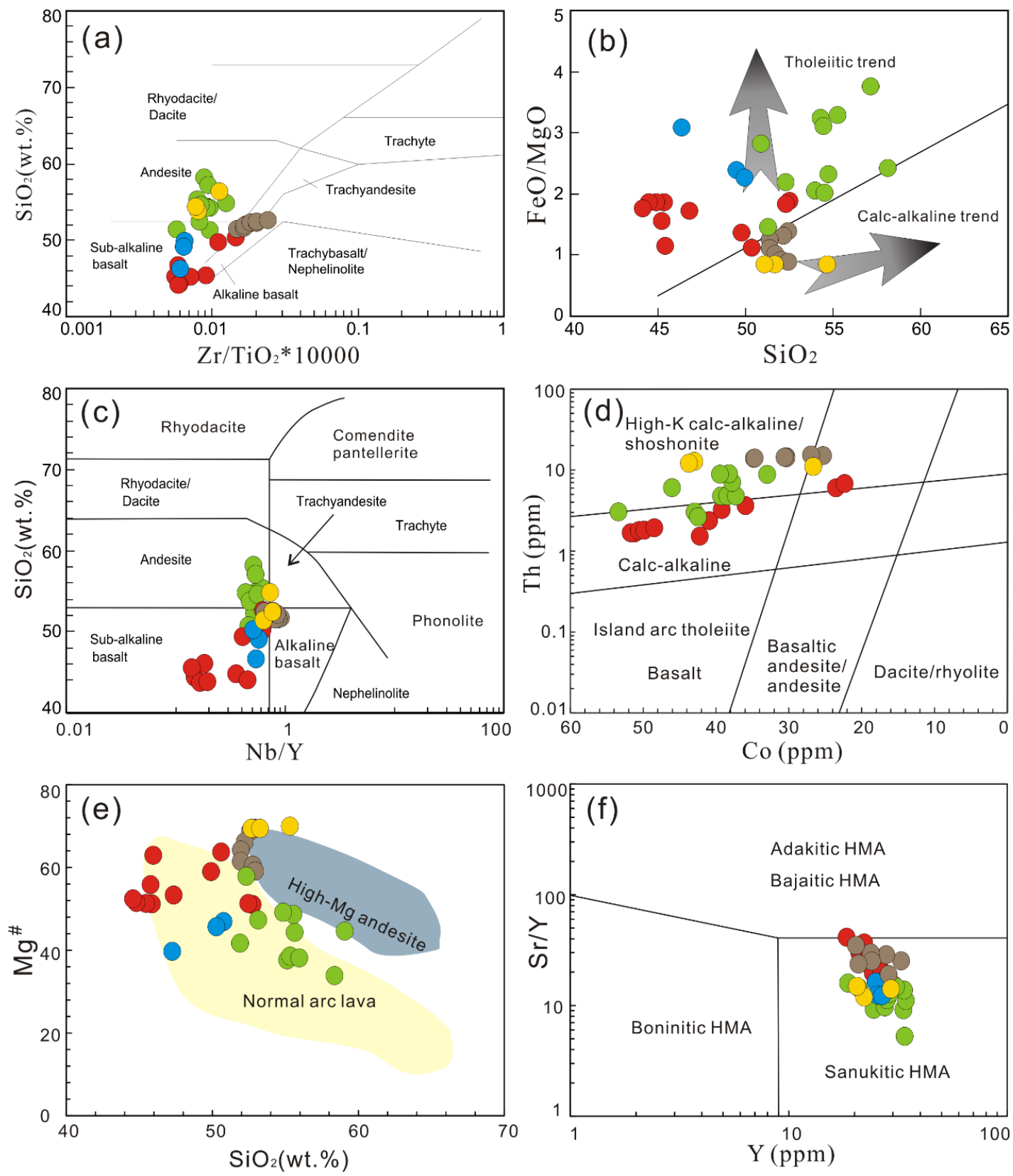

Figure 11. Plots of (a) $\mathrm{SiO}_{2}$ vs. $\mathrm{Zr} / \mathrm{TiO}_{2}$ [74], (b) $\mathrm{FeO} / \mathrm{MgO}$ vs. $\mathrm{SiO}_{2}$ [71], (c) $\mathrm{SiO}_{2}$ vs. Nb/Y [74], (d) Th vs. $\mathrm{Co}$ [75], (e) $\mathrm{Mg \#} \mathrm{vs.} \mathrm{SiO}_{2}$ [72], and (f) $\mathrm{Sr} / \mathrm{Y}$ vs. Y [72] for the Qianlishan and the South China Block (SCB) mafic rocks: data for the SCB mafic rocks are from Cen et al. [76], Chen et al. [20], Gan et al. [39], and Zhao et al. [77].

Different from the main-phase granites, the granite porphyry is A-type granite. However, the $\varepsilon \mathrm{Nd}(\mathrm{t})$ values of these samples are similar as those of main-phase granites and are plotted mainly close to the Precambrian crust of the SCB (Figure 6a,b). However, they show high ratios of $\mathrm{CaO} / \mathrm{Na}_{2} \mathrm{O}$ $(>17)$, suggesting that they originated from the partial melting of the ancient basement [81]. However, compared to the zircon $\varepsilon \mathrm{Hf}(\mathrm{t})$ of the ancient basement in subterranean south Hunan $(-17.9$ to -14.2 [82]) and the main-phase granites $(-8.3$ to 0.7$)$, the values of the granite porphyry samples $(-6.3$ to 3.9$)$ are 
much higher (Figure $6 \mathrm{c}, \mathrm{d}$ ). This indicates that the source of the granite porphyry has more contributions of mantle components than the main-phase granites. Therefore, the granite porphyry may also be a product of parental melting of the ancient basement mixed with mantle-derived components. The granite porphyry has positive correlations between $\mathrm{Zr}$ and $\mathrm{Ce} / \mathrm{Y}$, suggesting insignificant influence of fractional crystallization. Thus, the negative anomalies of Eu and $\mathrm{Sr}$ require partial melting of source rocks within the stability field of plagioclase. Although the granite porphyry exhibits high $\mathrm{La} / \mathrm{Yb}$ and $\mathrm{Dy} / \mathrm{Yb}$, the $\mathrm{Yb}$ content of granite porphyry (3.9-8.5 ppm) do not exhibit significant differences in the main phase granite (6.12-13.1 ppm). Therefore, we prefer that the high $\mathrm{La} / \mathrm{Yb}$ and $\mathrm{Dy} / \mathrm{Yb}$ of granite porphyry mainly inherit from the source [80]. Thus, we conclude that the source of the mantle-derived components of the granite porphyry is the Qianlishan mafic dykes, which display similar $\mathrm{Zr} / \mathrm{Nb}$ and $\mathrm{Zr} / \mathrm{Hf}$ ratios to the granite porphyry (Figure 12) and conform to the chronology results above. In addition, one sample of the granite porphyry shows significantly similar geochemical characteristics of high $\mathrm{La} / \mathrm{Yb}$ and LREE enrichment to the Qianlishan mafic dykes, as seen in Chondrite-normalized REE patterns (Figure 8). Therefore, we propose that granite porphyry is the product of partial melting of a hybrid source with the ancient basement and the Qianlishan mafic dykes.
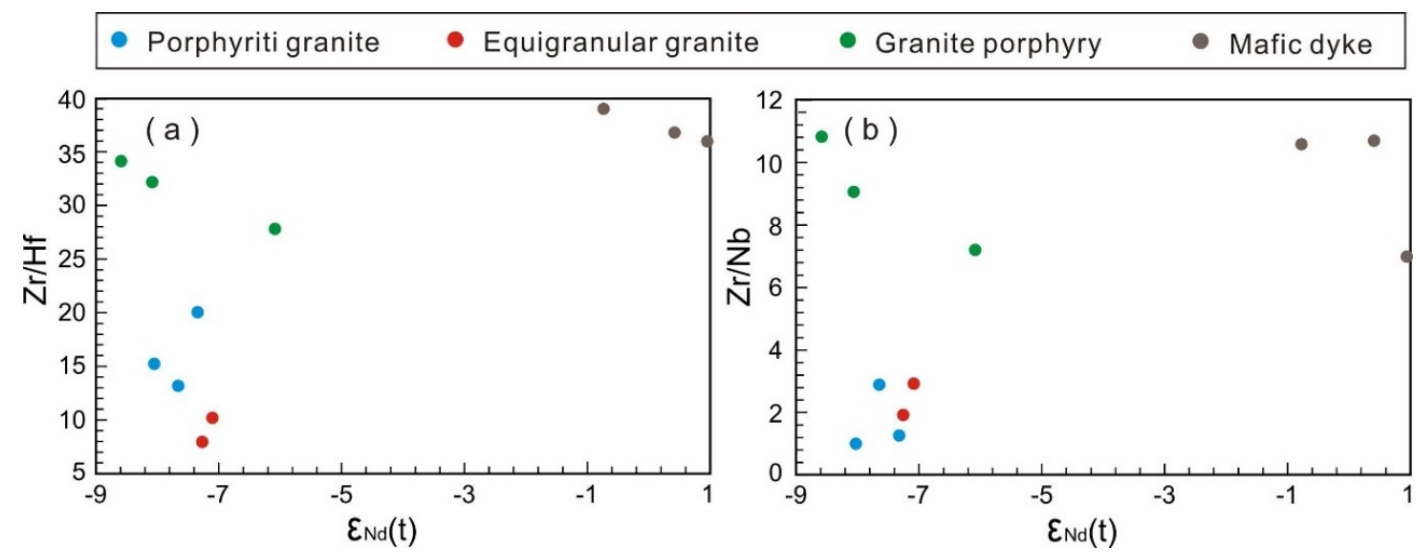

Figure 12. Plots of (a) $\mathrm{Zr} / \mathrm{Hf}$ vs. $\varepsilon \mathrm{Nd}(\mathrm{t})$ and (b) $\mathrm{Zr} / \mathrm{Nb}$ vs. $\varepsilon \mathrm{Nd}(\mathrm{t})$ showing the magmatic differentiation model.

\subsection{Tectonic Implications}

Previous studies have shown that HMA is common in the subduction zones, such as Japan and the Aleutian Islands, which are frequently considered products of partial melting of hydrous mantle peridotite or metasomatized lithospheric mantle [83-86]. Moreover, typical HMA is also observed within cratons, which are diversely interpreted as interactions between partial melts of eclogite and mantle peridotite (e.g., North China Craton [87]) and/or interactions of slab-derived components with an overlying mantle wedge [88-90].

The Qianlishan HMA in this study does not show adakitic affinity (Figure 11f) and is unlikely to be derived from interaction between partial melts of eclogite and mantle peridotite by lower foundering of the thick lower crust or dehydration of slabs [87,89]. A previous study of HMA in the Youjiang Basin suggested that its enriched $\varepsilon \mathrm{Nd}(\mathrm{t})(-7.8$ to -4.3$)$ and zircon $\varepsilon \mathrm{Hf}(\mathrm{t})(-14.0$ to -9.2$)$ are similar to early Paleozoic high-Mg rocks originating from ancient metasomatized SCLM associated with Neoproterozoic subduction along the Jiangnan Orogen [39]. In fact, some geochemical data of whole rock in this study are similar to those for HMA in the Youjiang Basin, e.g., Th/Sm (1.33-1.77), $\mathrm{Th} / \mathrm{Ce}(0.14-0.18), \mathrm{Th} / \mathrm{Yb}$ (3.73-5.12), Ba/La (12.8-20.5), Th/ $\mathrm{Nb}(0.59-0.74)$, and $\mathrm{Nb} / \mathrm{Yb}$ (5.17-6.44) ratios (Figures 13 and 14), suggesting the addition of subducted sediment-derived components [39,91]. However, the HMA in this study is different from early Paleozoic high-Mg rocks and HMA in the Youjiang Basin due to its significantly depleted whole-rock $\varepsilon \mathrm{Nd}(\mathrm{t})(-2.08$ to 0.73$)$ and zircon $\varepsilon \mathrm{Hf}(\mathrm{t})$ ( -4.4 to 4.3; Figure 6). Moreover, the Qianlishan HMA consists of HMA and enriched mid-ocean 
ridge basalts (EMORB)-like tholeiitic dolerites (Figure 14a,b [92]). The EMORB-like tholeiitic dolerites exhibit depleted $\varepsilon \mathrm{Nd}(\mathrm{t})$ with high $\mathrm{Ba} / \mathrm{La}(12.8-20.5)$ and arc-like $\mathrm{Nb}$-Ta-Ti anomalies, suggesting an affinity to back-arc basalt (Figures 8 and 14c [93]). The diagram of $\varepsilon \mathrm{Nd}(\mathrm{t}) \mathrm{vs}$. La/ $\mathrm{Nb}$ further suggests that the Qianlishan HMA could be the result of mixing melts of depleted asthenospheric mantle and metasomatized SCLM (Figure 15). Based on such signatures, we thus infer the following processes to explain genesis of the Qianlishan complex: (1) the slab roll-back may have led to generation of Qianlishan back-arc basalt and HMA, and the HMA further formed the Qianlishan mafic dykes in the Late Jurassic; (2) asthenospheric underplating led to mantle and crust interaction, and lithospheric mantle in the SCB melted, resulting in the formation of Qianlishan granites during the Late Jurassic (Figure 16).

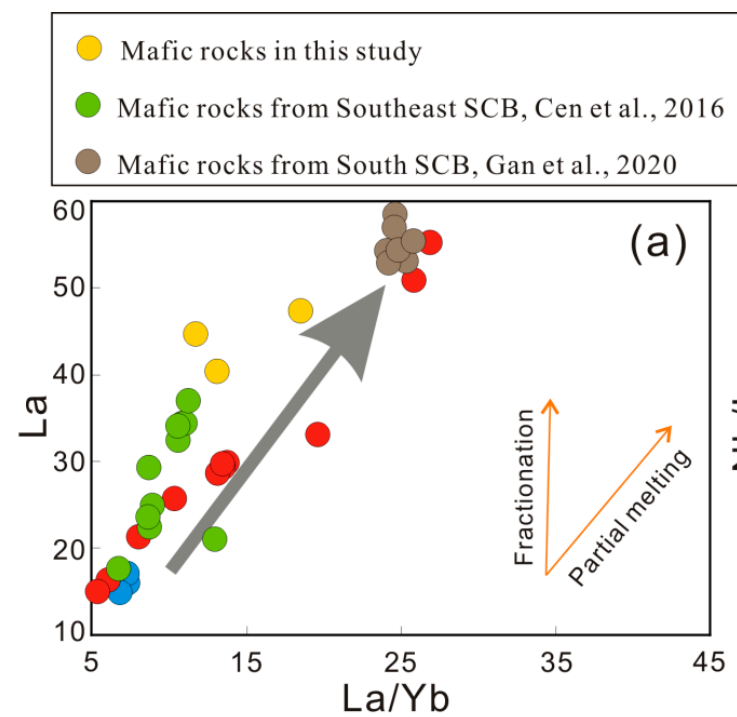

Mafic rocks of Qianlishan, Chen et al., 2014

Mafic rocks from North SCB, Zhao et al., 2010
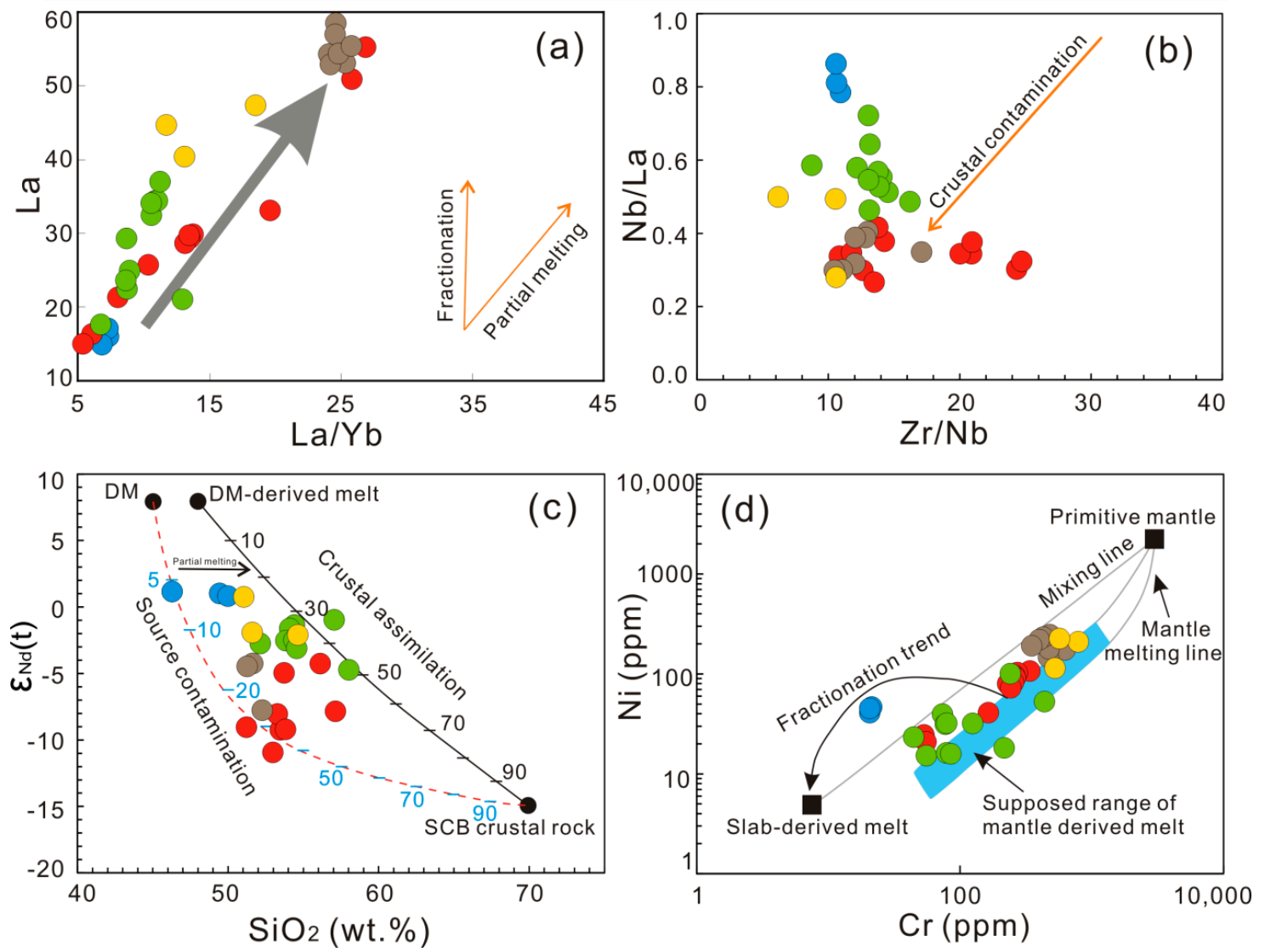

Figure 13. Plots of (a) La vs. $\mathrm{La} / \mathrm{Yb}$, (b) $\mathrm{Nb} / \mathrm{La}$ vs. $\mathrm{Zr} / \mathrm{Nb}$, (c) $\varepsilon \mathrm{Nd}(\mathrm{t}) \mathrm{vs}$. $\mathrm{SiO}_{2}$, and (d) $\mathrm{Ni}$ vs. Cr [39] for the Qianlishan and the SCB mafic rocks: cited data are the same as in Figure 11. The DM in (c) is marked by $\mathrm{SiO}_{2}=45$ wt. $\%, \mathrm{Nd}=4.0 \mathrm{ppm}, \varepsilon \mathrm{Nd}(\mathrm{t})=+8.0$, and $\mathrm{Nb} / \mathrm{La}=0.75$; its derivation is marked by $\mathrm{SiO}_{2}=48 \mathrm{wt} . \%, \mathrm{Nd}=20 \mathrm{ppm}, \varepsilon \mathrm{Nd}(\mathrm{t})=+8.0$, and $\mathrm{Nb} / \mathrm{La}=0.75$; and the SCB crustal rock is marked by $\mathrm{SiO}_{2}=70 \mathrm{wt} . \%, \mathrm{Nd}=26.3 \mathrm{ppm}, \varepsilon \mathrm{Nd}(\mathrm{t})=-15.0$, and $\mathrm{Nb} / \mathrm{La}=0.32$. The fields for different rocks in $(\mathrm{d})$ are from Zhang et al. [86] and the references therein. 

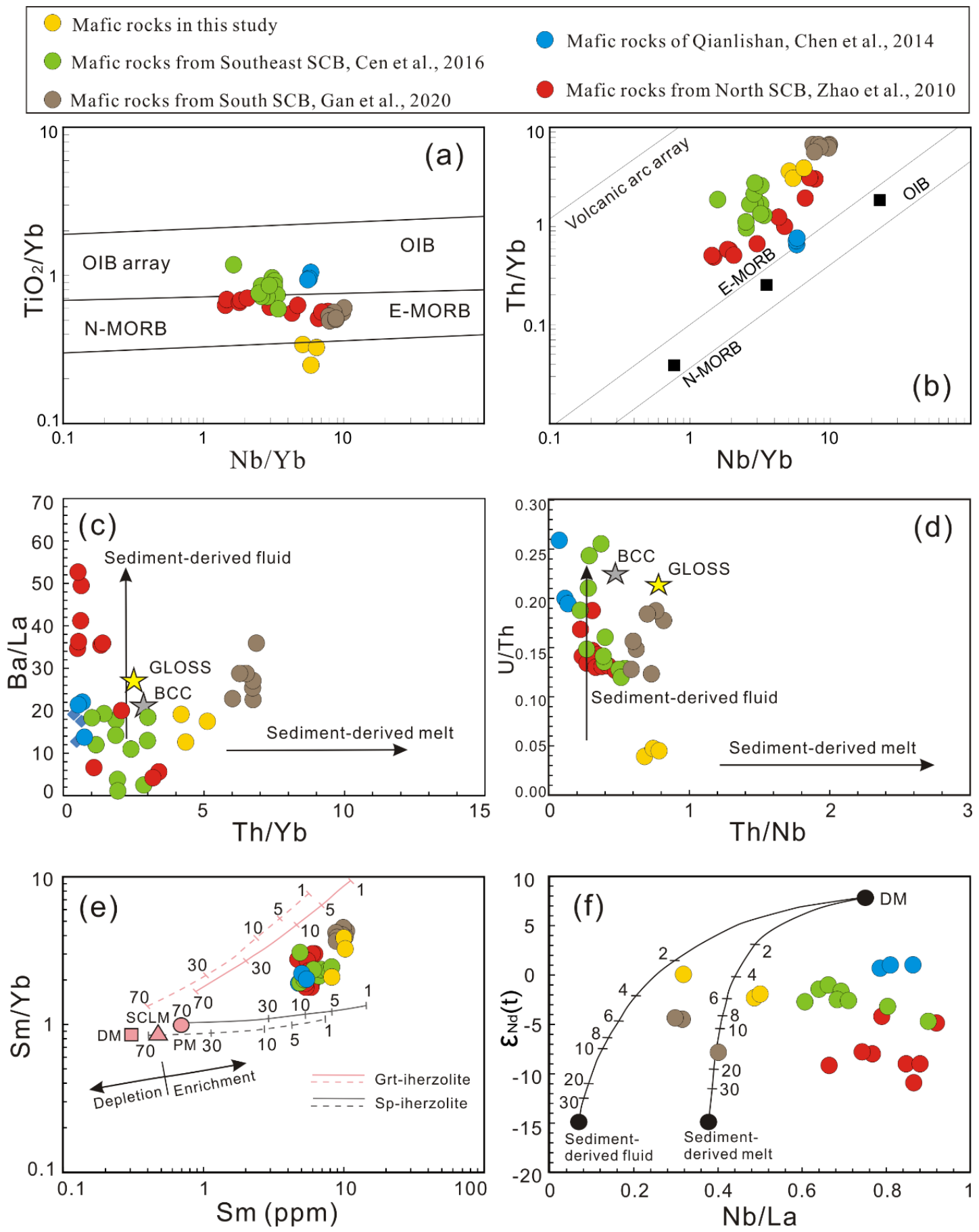

Figure 14. Plots of (a) $\mathrm{TiO}_{2} / \mathrm{Yb}$ vs. $\mathrm{Nb} / \mathrm{Yb}$, (b) $\mathrm{Th} / \mathrm{Yb}$ vs. $\mathrm{Nb} / \mathrm{Yb}$ [94], (c) $\mathrm{Ba} / \mathrm{La}$ vs. $\mathrm{Th} / \mathrm{Yb}$, (d) U/Th vs. $\mathrm{Yh} / \mathrm{Nb}$, (e) Sm/Yb vs. Sm, and (f) $\varepsilon N d(t)$ vs. Nb/La [39] for the Qianlishan and the SCB mafic rocks: cited data are the same as in Figure 11. Normal mid-ocean ridge basalts (N-MORB), enriched mid-ocean ridge basalts (E-MORB), and oceanic island basalts (OIB) of (b) are cited from [94]. The fields of the global subducting sediment (GLOSS) and bulk continental crust (BCC) in (c,d) are from Plank and Langmuir [92]. The dashed and solid lines of (e) are melting trends for the DM ( $\mathrm{Sm}=0.3 \mathrm{ppm}$ and $\mathrm{Sm} / \mathrm{Yb}=0.86$ [95]) and the SCLM ( $\mathrm{Sm}=0.6 \mathrm{ppm}$ and $\mathrm{Sm} / \mathrm{Yb}=0.96$ [96]). The DM of (f) is represented by $\mathrm{La}=0.4 \mathrm{ppm}, \mathrm{Nb}=0.3 \mathrm{ppm}, \mathrm{Nd}=4.0 \mathrm{ppm}$, and $\varepsilon \mathrm{Nd}(\mathrm{t})=+8$ [97]; sediment-derived fluid is represented by $\mathrm{La}=37.5 \mathrm{ppm}, \mathrm{Nb}=2.25 \mathrm{ppm}, \mathrm{Nd}=75 \mathrm{ppm}$, and $\varepsilon \mathrm{Nd}(\mathrm{t})=-15$; and sediment-derived melt is represented by $\mathrm{La}=47.6 \mathrm{ppm}, \mathrm{Nb}=17.8 \mathrm{ppm}, \mathrm{Nd}=51.4 \mathrm{ppm}$, and $\varepsilon \mathrm{Nd}(\mathrm{t})=-15$ [98]. 

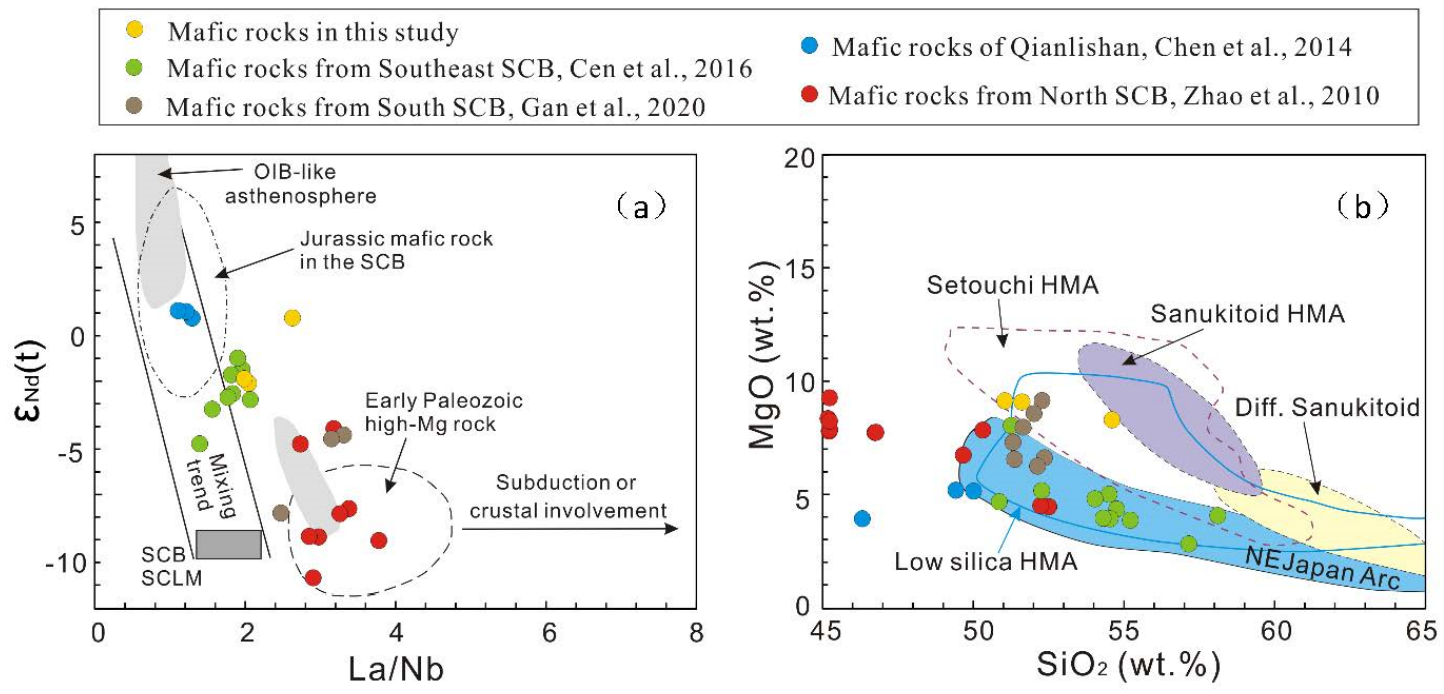

Figure 15. Plots of (a) $\varepsilon \mathrm{Nd}(\mathrm{t}) \mathrm{vs.} \mathrm{La} / \mathrm{Nb}[39,99]$ and (b) $\mathrm{MgO}$ vs. $\mathrm{SiO}_{2}$ [94] for the Qianlishan and the SCB mafic rocks: cited data are the same as in Figure 11. Early Paleozoic high-Mg rock from Yao et al. [100] and Wang et al. [101]; Jurassic mafic rock in the SCB and SCLM from Gan et al. [39].

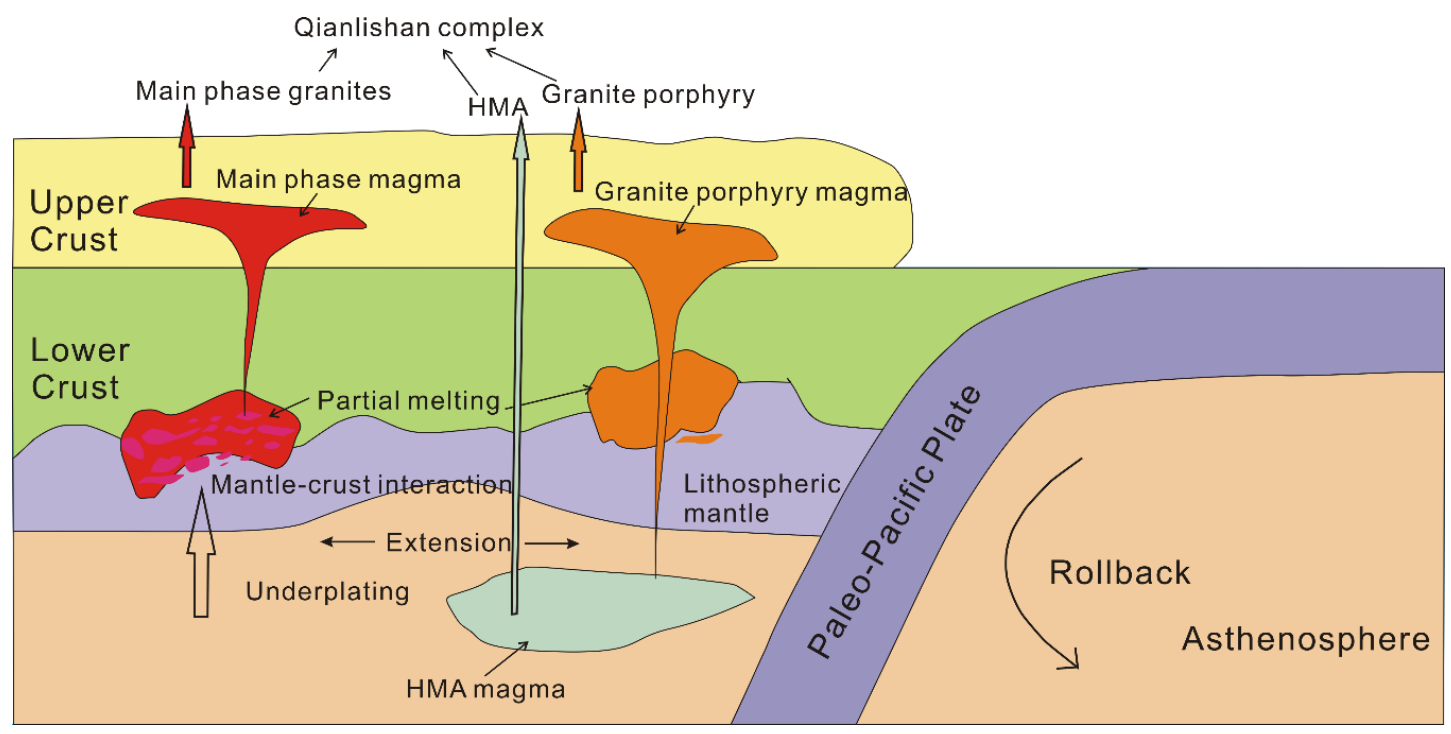

Figure 16. Schematic illustration of the petrogenetic mechanism of the Qianlishan high-Mg andesite (HMA) and Qianlishan granites.

\section{Conclusions}

1. The Qianlishan complex consists of the main-phase porphyritic and equigranular granites, granite porphyry, and mafic dykes with emplacement ages at $158.9 \pm 1.1,157.8 \pm 1.4,144.5 \pm 1.0$, and $157.6 \pm 1.8 \mathrm{Ma}$, respectively.

2. The main-phase granites are high-K, calc-alkaline, and highly fractionated S-type granites. The granite porphyry is A-type granite. The mafic dykes are characterized by high-Mg andesite (HMA).

3. The main-phase granites are derived from a hybrid source of crust which involved a mantle-derived component. The granite porphyry is the product of partial melting of a hybrid source with Qianlishan mafic rocks and ancient basement. The Qianlishan mafic dykes are derived from mixing melts of depleted asthenospheric mantle and metasomatized SCLM. 
Supplementary Materials: The following are available online at http://www.mdpi.com/2075-163X/10/12/1069/s1, Table S1: LA-ICP-MS U-Pb isotopic data of zircon of the Qianlishan complex, Table S2: Hf isotopic data of zircons separated from the Qianlishan complex, Table S3: Major and trace elements of the Qianlishan complex, Table S4: Whole-rock Nd isotopic data of the Qianlishan complex, Table S5: Synthesis of the ages of the Qianlishan complex.

Author Contributions: Conceptualization, Z.-F.Y. and Z.Z.; methodology, Z.-F.Y. and Y.X.; investigation, Z.-F.Y., Y.-Q.W. and H.W.; writing-original draft preparation, Z.-F.Y.; writing-review and editing, Z.-F.Y., Q.-M.P. and Z.Z.; project administration, P.-A.W.; funding acquisition, Z.Z. All authors have read and agreed to the published version of the manuscript.

Funding: This research was funded by the National Key Research and Development Plan (No. 2016YFC0600208), by the National Nonprofit Institute Research Grant of Chinese Academy of Geological Sciences (No. JYYWF20180502), and by the National Science Foundation of China (No. 41973046).

Acknowledgments: We express our acknowledgement for reviews by Winston Wen Zhao and Xin-You Zhu. $\mathrm{Yu} \mathrm{Mu}$ and Yan-Lin Zhu are thanked for support for the figures.

Conflicts of Interest: The authors declare no conflict of interest.

\section{References}

1. Werner, A.B.; Sinclair, W.D.; Amey, E.B. International strategic mineral issues summary report: Tungsten. Circular 1998, 2014. [CrossRef]

2. Aksyuk, A.M. Estimation of Fluorine Concentrations in Fluids of Mineralized Skarn Systems. Econ. Geol. 2000, 95, 1339-1347. [CrossRef]

3. Černý, P.; Blevin, P.L.; Cuney, M.; London, D. Granite-Related Ore Deposits. Econ. Geol. 2005, 2005, 337-370. [CrossRef]

4. Ray, G.E.; Webster, I.C.L.; Ballantyne, S.B.; Kilby, C.E.; Cornelius, S.B. The Geochemistry of Three Tin-Bearing Skarns and TheirRelated Plutonic Rocks, Atlin, Northern British Columbia. Econ. Geol. 2000, 95, 1349-1365. [CrossRef]

5. Mao, J.; Yanbo, C.; Maohong, C.; Pirajno, F. Major types and time-space distribution of Mesozoic ore deposits in South China and their geodynamic settings. Miner. Depos. 2013, 48, 267-294. [CrossRef]

6. Richards, J.P. Magmatic to hydrothermal metal fluxes in convergent and collided margins. Ore Geol. Rev. 2011, 40, 1-26. [CrossRef]

7. Zhao, W.W.; Zhou, M.-F.; Li, Y.H.M.; Zhao, Z.; Gao, J.-F. Genetic types, mineralization styles, and geodynamic settings of Mesozoic tungsten deposits in South China. J. Asian Earth Sci. 2017, 137, 109-140. [CrossRef]

8. Chen, C.-H.; Lin, W.; Lan, C.-Y.; Lee, C.-Y. Geochemical, $\mathrm{Sr}$ and Nd isotopic characteristics and tectonic implications for three stages of igneous rock in the Late Yanshanian (Cretaceous) orogeny, SE China. Earth Environ. Sci. Trans. R. Soc. Edinb. 2004, 95, 237-248. [CrossRef]

9. Holwell, D.A.; Fiorentini, M.; McDonald, I.; Lu, Y.; Giuliani, A.; Smith, D.J.; Keith, M.; Locmelis, M. A metasomatized lithospheric mantle control on the metallogenic signature of post-subduction magmatism. Nat. Commun. 2019, 10, 3511. [CrossRef]

10. Li, J.; Dong, S.; Zhang, Y.; Zhao, G.; Johnston, S.T.; Cui, J.; Xin, Y. New insights into Phanerozoic tectonics of south China: Part 1, polyphase deformation in the Jiuling and Lianyunshan domains of the central Jiangnan Orogen. J. Geophys. Res. Solid Earth 2016, 121, 3048-3080. [CrossRef]

11. Shu, L.S.; Faure, M.; Yu, J.-H.; Jahn, B.-M. Geochronological and geochemical features of the Cathaysia block (South China): New evidence for the Neoproterozoic breakup of Rodinia. Precambrian Res. 2011, 187, 263-276. [CrossRef]

12. Ling, M.-X.; Wang, F.-Y.; Ding, X.; Hu, Y.-H.; Zhou, J.-B.; Zartman, R.E.; Yang, X.-Y.; Sun, W. Cretaceous Ridge Subduction Along The Lower Yangtze River Belt, Eastern China. Econ. Geol. 2009, 104, 303-321. [CrossRef]

13. Zhao, J.-H.; Zhou, M.-F.; Yan, D.-P.; Zheng, J.P.; Li, J.-W. Reappraisal of the ages of Neoproterozoic strata in South China: No connection with the Grenvillian orogeny. Geology 2011, 39, 299-302. [CrossRef]

14. Li, H.; Palinkaš, L.A.; Watanabe, K.; Xi, X.-S. Petrogenesis of Jurassic A-type granites associated with $\mathrm{Cu}-\mathrm{Mo}$ and W-Sn deposits in the central Nanling region, South China: Relation to mantle upwelling and intra-continental extension. Ore Geol. Rev. 2018, 92, 449-462. [CrossRef] 
15. Cao, J.; Yang, X.; Du, J.; Wu, Q.; Kong, H.; Li, H.; Wan, Q.; Xi, X.; Gong, Y.; Zhao, H. Formation and geodynamic implication of the Early Yanshanian granites associated with W-Sn mineralization in the Nanling range, South China: An overview. Int. Geol. Rev. 2018, 60, 1744-1771. [CrossRef]

16. Vigneresse, J.-L. The role of discontinuous magma inputs in felsic magma and ore generation. Ore Geol. Rev. 2007, 30, 181-216. [CrossRef]

17. Yu, K.; Liu, Y.; Hu, Q.; Ducea, M.N.; Hu, Z.; Zong, K.; Chen, H. Magma Recharge and Reactive Bulk Assimilation in Enclave-Bearing Granitoids, Tonglu, South China. J. Petrol. 2018, 59, 795-824. [CrossRef]

18. Zhou, X.; Sun, T.; Shen, W.; Shu, L.; Niu, A.Y. Petrogenesis of Mesozoic granitoids and volcanic rocks in South China: A response to tectonic evolution. Episodes 2006, 29, 26-33. [CrossRef]

19. Zhao, K.-D.; Jiang, S.-Y.; Yang, S.-Y.; Dai, B.-Z.; Lu, J.-J. Mineral chemistry, trace elements and Sr-Nd-Hf isotope geochemistry and petrogenesis of Cailing and Furong granites and mafic enclaves from the Qitianling batholith in the Shi-Hang zone, South China. Gondwana Res. 2012, 22, 310-324. [CrossRef]

20. Chen, B.; Ma, X.; Wang, Z. Origin of the fluorine-rich highly differentiated granites from the Qianlishan composite plutons (South China) and implications for polymetallic mineralization. J. Asian Earth Sci. 2014, 93, 301-314. [CrossRef]

21. Lu, H.-Z.; Liu, Y.; Wang, C.; Xu, Y.; Li, H. Mineralization and fluid inclusion study of the Shizhuyuan W-Sn-Bi-Mo-F skarn deposit, Hunan Province, China. Econ. Geol. 2003, 98, 955-974. [CrossRef]

22. Mao, J.; Li, H.; Shimazaki, H.; Raimbault, L.; Guy, B. Geology and Metallogeny of the Shizhuyuan Skarn-Greisen Deposit, Hunan Province, China. Int. Geol. Rev. 1996, 38, 1020-1039. [CrossRef]

23. Wang, C.; Luo, S.; Xu, Y.; Sun, Y.; Xie, C.; Zhang, C.; Xu, W.; Ren, X. Geology of the Shizhuyuan Tungsten Multimetal Deposit; Geological Publishing House: Beijing, China, 1987; pp. 29-48. (In Chinese)

24. Guo, C.-L.; Wang, R.-C.; Yuan, S.-D.; Wu, S.-H.; Yin, B. Geochronological and geochemical constraints on the petrogenesis and geodynamic setting of the Qianlishan granitic pluton, Southeast China. Miner. Pet. 2014, 109, 253-282. [CrossRef]

25. Jiang, Y.-H.; Jiang, S.-Y.; Zhao, K.-D.; Ling, H.-F. Petrogenesis of Late Jurassic Qianlishan granites and mafic dykes, Southeast China: Implications for a back-arc extension setting. Geol. Mag. 2006, 143, 457-474. [CrossRef]

26. Mao, J.; Li, H.; Pei, Y. Geology and geochemistry of the Qianlishan granite stock and its relationship to polymetallic Tungsten mineralization. Miner. Depos. 1995, 14, 12-25, (In Chinese with English abstract).

27. Zhao, W.W.; Zhou, M.-F. Mineralogical and metasomatic evolution of the Jurassic Baoshan scheelite skarn deposit, Nanling, South China. Ore Geol. Rev. 2018, 95, 182-194. [CrossRef]

28. Hu, R.-Z.; Zhou, M.-F. Multiple Mesozoic mineralization events in South China-an introduction to the thematic issue. Miner. Depos. 2012, 47,579-588. [CrossRef]

29. Yan, D.-P.; Zhou, M.-F.; Song, H.-L.; Wang, X.-W.; Malpas, J. Origin and tectonic significance of a Mesozoic multi-layer over-thrust system within the Yangtze Block (South China). Tectonophysics 2003, 361, 239-254. [CrossRef]

30. Chen, P.; Hua, R.; Zhang, B.; Lu, J.; Fan, C. Early Yanshanian post-orogenic granitoids in the Nanling region. Sci. China Ser. D Earth Sci. 2002, 45, 755-768. [CrossRef]

31. Hua, R.-M.; Chen, P.-R.; Zhang, W.-L.; Yao, J.-M.; Lin, J.-F.; Zhang, Z.-S.; Gu, S.-Y. Metallogeneses and Their Geodynamic Settings Related to Mesozoic Granitoids in the Nanling Range. Geol. J. China Univ. 2005, 11, 291-304. (In Chinese with English abstract).

32. Li, X.-H.; Li, W.; Li, Z.-X. On the genetic classification and tectonic implications of the Early Yanshanian granitoids in the Nanling Range, South China. Chin. Sci. Bull. 2007, 52, 1873-1885. [CrossRef]

33. Hu, R.-Z.; Chen, W.T.; Xu, D.-R.; Zhou, M.-F. Reviews and new metallogenic models of mineral deposits in South China: An introduction. J. Asian Earth Sci. 2017, 137, 1-8. [CrossRef]

34. Mao, J.; Pirajno, F.; Cook, N.J. Mesozoic metallogeny in East China and corresponding geodynamic settings-An introduction to the special issue. Ore Geol. Rev. 2011, 43, 1-7. [CrossRef]

35. Peng, J.; Zhou, M.-F.; Hu, R.; Shen, N.; Yuan, S.; Bi, X.; Du, A.; Qu, W. Precise molybdenite Re-Os and mica Ar-Ar dating of the Mesozoic Yaogangxian tungsten deposit, central Nanling district, South China. Miner. Depos. 2006, 41, 661-669. [CrossRef]

36. Guo, F.; Fan, W.-M.; Wang, Y.; Li, C.-W. Upper Paleozoic Basalts in the Southern Yangtze Block: Geochemical and Sr-Nd Isotopic Evidence for Asthenosphere-Lithosphere Interaction and Opening of the Paleo-Tethyan Ocean. Int. Geol. Rev. 2004, 46, 332-346. [CrossRef] 
37. Zhou, M.-F.; Zhao, J.-H.; Qi, L.; Su, W.; Hu, R. Zircon U-Pb geochronology and elemental and Sr-Nd isotope geochemistry of Permian mafic rocks in the Funing area, SW China. Contrib. Mineral. Petrol. 2006, 151, 1-19. [CrossRef]

38. Lai, S.-C.; Qin, J.; Li, Y.; Li, S.; Santosh, M. Permian high Ti/Y basalts from the eastern part of the Emeishan Large Igneous Province, southwestern China: Petrogenesis and tectonic implications. J. Asian Earth Sci. 2012, 47, 216-230. [CrossRef]

39. Gan, C.; Wang, Y.; Barry, T.L.; Zhang, Y.; Qian, X. Late Jurassic high-Mg andesites in the Youjiang Basin and their significance for the southward continuation of the Jiangnan Orogen, South China. Gondwana Res. 2020, 77, 260-273. [CrossRef]

40. Chen, Y.; Li, H.; Sun, W.; Ireland, T.; Tian, X.; Hu, Y.; Yang, W.; Chen, C.; Xu, D. Generation of Late Mesozoic Qianlishan A 2 -type granite in Nanling Range, South China: Implications for Shizhuyuan W-Sn mineralization and tectonic evolution. Lithos 2016, 266-267, 435-452. [CrossRef]

41. Wiedenbeck, M.; Hanchar, J.M.; Peck, W.H.; Sylvester, P.; Valley, J.; Whitehouse, M.; Kronz, A.; Morishita, Y.; Nasdala, L.; Fiebig, J.; et al. Further Characterisation of the 91500 Zircon Crystal. Geostand. Geoanalytical Res. 2004, 28, 9-39. [CrossRef]

42. Andersen, T. Correction of common lead in $\mathrm{U}-\mathrm{Pb}$ analyses that do not report 204Pb. Chem. Geol. 2002, 192, 59-79. [CrossRef]

43. Ludwig, K.R. User's Manual for Isoplot 3.00: A Geochronological Toolkit for Microsoft Excel; Berkeley Geochronology Center Special Publication: Berkeley, CA, USA, 2003; Volume 4, p. 70.

44. Black, L.P.; Kamo, S.L.; Allen, C.M.; Davis, D.W.; Aleinikoff, J.N.; Valley, J.W.; Mundil, R.; Campbell, I.H.; Korsch, R.J.; Williams, I.S.; et al. Improved 206Pb/238U microprobe geochronology by the monitoring of a trace-element-related matrix effect; SHRIMP, ID-TIMS, ELA-ICP-MS and oxygen isotope documentation for a series of zircon standards. Chem. Geol. 2004, 205, 115-140. [CrossRef]

45. Wu, F.-Y.; Yang, Y.; Xie, L.-W.; Yang, J.; Xu, P. Hf isotopic compositions of the standard zircons and baddeleyites used in U-Pb geochronology. Chem. Geol. 2006, 234, 105-126. [CrossRef]

46. Xie, L.; Zhang, Y.; Zhang, H.; Sun, J.; Wu, F.-Y. In situ simultaneous determination of trace elements, U-Pb and Lu-Hf isotopes in zircon and baddeleyite. Sci. Bull. 2008, 53, 1565-1573. [CrossRef]

47. Iizuka, T.; Hirata, T. Improvements of precision and accuracy in in situ Hf isotope microanalysis of zircon using the laser ablation-MC-ICPMS technique. Chem. Geol. 2005, 220, 121-137. [CrossRef]

48. Chu, N.-C.; Taylor, R.N.; Chavagnac, V.; Nesbitt, R.W.; Boella, R.M.; Milton, J.A.; German, C.R.; Bayon, G.; Burton, K. Hf isotope ratio analysis using multi-collector inductively coupled plasma mass spectrometry: An evaluation of isobaric interference corrections. J. Anal. At. Spectrom. 2002, 17, 1567-1574. [CrossRef]

49. Wang, Y.; Gu, T.; Wang, X.; Gao, Y.; Jochum, K.P.; Müller, W.E.G. Practical Handbook of Reference Materials for Geoanalysis, 2nd ed.; Geological Publishing House: Beijing, China, 2013; (Chinese-English).

50. Luo, D.H.; Wu, S.Q.; Wu, X.J.; Gan, L.; Deng, Y.J.; Wen, H.L.; Hang, H.M.; Lv, C.F. Laboratory Information Management System in National Research Center for Geoanalysis. Rock Miner. Anal. 2011, 110-115. (In Chinese with English abstract). [CrossRef]

51. Zhu, C.Y.; Zhao, G.; Ji, J.; Sun, M.; Han, Y.; Liu, Q.; Eizenhöfer, P.R.; Zhang, X.; Hou, W. Subduction between the Jiamusi and Songliao blocks: Geological, geochronological and geochemical constraints from the Heilongjiang Complex. Lithos 2017, 282-283, 128-144. [CrossRef]

52. Hoskin, P.W.O. The Composition of Zircon and Igneous and Metamorphic Petrogenesis. Rev. Miner. Geochem. 2003, 53, 27-62. [CrossRef]

53. Weizhou, S.; Dezi, W.; Changshi, L. Isotope Geochemical Characteristics and Material Sources of Tin-Bearing Porphyries in South China. Acta Geol. Sin. 1996, 9, 181-192. [CrossRef]

54. Middlemost, E.A. Naming materials in the magma/igneous rock system. Earth Sci. Rev. 1994, 37, $215-224$. [CrossRef]

55. Maniar, P.D.; Piccoli, P.M. Tectonic discrimination of granitoids. GSA Bull. 1989, 101, 635-643. [CrossRef]

56. Rickwood, P.C. Boundary lines within petrologic diagrams which use oxides of major and minor elements. Lithos 1989, 22, 247-263. [CrossRef]

57. Sylvester, P.J. Post-Collisional Alkaline Granites. J. Geol. 1989, 97, 261-280. [CrossRef]

58. Kelemen, P.B.; Yogodzinski, G.M.; Scholl, D.W. Along-Strike Variation in the Aleutian Island Arc: Genesis of High Mg\# Andesite and Implications for Continental Crust. In Inside the Subduction Factory; John Wiley \& Sons, Ltd.: Hoboken, NJ, USA, 2003; pp. 223-276. [CrossRef] 
59. Tatsumi, Y. High-Mg Andesites in the Setouchi Volcanic Belt, Southwestern Japan: Analogy to Archean Magmatism and Continental Crust Formation? Annu. Rev. Earth Planet. Sci. 2006, 34, 467-499. [CrossRef]

60. McDonough, W.; Sun, S.-S. The composition of the Earth. Chem. Geol. 1995, 120, 223-253. [CrossRef]

61. Li, X.-H.; Liu, D.; Sun, M.; Li, W.-X.; Liang, X.-R.; Liu, Y. Precise Sm-Nd and U-Pb isotopic dating of the supergiant Shizhuyuan polymetallic deposit and its host granite, SE China. Geol. Mag. 2004, 141, 225-231. [CrossRef]

62. Liu, X.F.; Yuan, S.D.; Wu, S.H. Re-Os dating of the molybdenite from the Jinchuantang tin-bismuth deposit in Hunan Province and its geological significance. Acta Petrol. Sinica 2012, 28, 39-51, (In Chinese with English abstract).

63. Li, X.; Liu, X.; Liu, Y.; Su, L.; Sun, W.; Huang, H.-Q.; Yi, K. Accuracy of LA-ICPMS zircon U-Pb age determination: An inter-laboratory comparison. Sci. China Earth Sci. 2015, 58, 1722-1730. [CrossRef]

64. Whalen, J.B.; Currie, K.L.; Chappell, B.W. A-type granites: Geochemical characteristics, discrimination and petrogenesis. Contrib. Miner. Pet. 1987, 95, 407-419. [CrossRef]

65. King, P.; White, A.; Chappell, B.; Allen, C. Characterization and Origin of Aluminous A-type Granites from the Lachlan Fold Belt, Southeastern Australia. J. Pet. 1997, 38, 371-391. [CrossRef]

66. Loiselle, M.C. Characteristics and origin of anorogenic granites. Geol. Soc. Am. Abstr. Programs 1979, 11, 468.

67. Chappell, B. Aluminium saturation in I- and S-type granites and the characterization of fractionated haplogranites. Lithos 1999, 46, 535-551. [CrossRef]

68. Zhang, L.-X.; Wang, Q.; Zhu, D.-C.; Li, S.-M.; Zhao, Z.-D.; Zhang, L.-L.; Chen, Y.; Liu, S.-A.; Zheng, Y.-C.; Wang, R.; et al. Generation of leucogranites via fractional crystallization: A case from the Late Triassic Luoza batholith in the Lhasa Terrane, southern Tibet. Gondwana Res. 2019, 66, 63-76. [CrossRef]

69. Wolf, M.B.; London, D. Apatite dissolution into peraluminous haplogranitic melts: An experimental study of solubilities and mechanisms. Geochim. Cosmochim. Acta 1994, 58, 4127-4145. [CrossRef]

70. Jahn, B.-M.; Wu, F.; Capdevila, R.; Martineau, F.; Zhao, Z.; Wang, Y. Highly evolved juvenile granites with tetrad REE patterns: The Woduhe and Baerzhe granites from the Great Xing'an Mountains in NE China. Lithos 2001, 59, 171-198. [CrossRef]

71. Miyashiro, A. Volcanic rock series in island arcs and active continental margins. Am. J. Sci. 1974, 274, 321-355. [CrossRef]

72. Kamei, A. High-Mg diorites derived from sanukitic HMA magmas, Kyushu Island, southwest Japan arc: Evidence from clinopyroxene and whole rock compositions. Lithos 2004, 75, 359-371. [CrossRef]

73. Defant, M.J.; Drummond, M.S. Derivation of some modern arc magmas by melting of young subducted lithosphere. Nat. Cell Biol. 1990, 347, 662-665. [CrossRef]

74. Winchester, J.; Floyd, P. Geochemical discrimination of different magma series and their differentiation products using immobile elements. Chem. Geol. 1977, 20, 325-343. [CrossRef]

75. Hastie, A.R.; Kerr, A.C.; Pearce, J.A.; Mitchell, S.F. Classification of Altered Volcanic Island Arc Rocks using Immobile Trace Elements: Development of the Th-Co Discrimination Diagram. J. Petrol. 2007, 48, 2341-2357. [CrossRef]

76. Cen, T.; Li, W.-X.; Wang, X.-C.; Pang, C.-J.; Li, Z.; Xing, G.-F.; Zhao, X.; Tao, J. Petrogenesis of early Jurassic basalts in southern Jiangxi Province, South China: Implications for the thermal state of the Mesozoic mantle beneath South China. Lithos 2016, 256-257, 311-330. [CrossRef]

77. Zhao, J.-H.; Zhou, M.-F.; Zheng, J.-P. Metasomatic mantle source and crustal contamination for the formation of the Neoproterozoic mafic dike swarm in the northern Yangtze Block, South China. Lithos 2010, 115, 177-189. [CrossRef]

78. Griffin, W.L.; Wang, X.; Jackson, S.E.; Pearson, N.J.; O’Reilly, S.Y.; Xu, X.; Zhou, X. Zircon chemistry and magma mixing, SE China: In-situ analysis of Hf isotopes, Tonglu and Pingtan igneous complexes. Lithos 2002, 61, 237-269. [CrossRef]

79. Champion, D.C.; Bultitude, R.J. The geochemical and SrNd isotopic characteristics of Paleozoic fractionated S-types granites of north Queensland: Implications for S-type granite petrogenesis. Lithos 2013, 162-163, 37-56. [CrossRef]

80. Wang, G.-C.; Jiang, Y.-H.; Liu, Z.; Ni, C.-Y.; Qing, L.; Zhang, Q. Elemental and Sr-Nd-Hf isotopic constraints on the origin of Late Jurassic adakitic granodiorite in central Fujian province, southeast China. Miner. Pet. 2015, 109, 501-518. [CrossRef] 
81. Sylvester, P.J. Post-collisional strongly peraluminous granites. Lithos 1998, 45, 29-44. [CrossRef]

82. Wang, P. The Geochemistry and Geochronology Comprehensive Study of Precambrian-Cambrian Strata in Hunan and Guangxi Province; Nanjing University: Nanjing, China, 2012.

83. Johnston, A.D.; Wyllie, P.J. The system tonalite-peridotite- $\mathrm{H}_{2} \mathrm{O}$ at $30 \mathrm{kbar}$, with applications to hybridization in subduction zone magmatism. Contrib. Miner. Pet. 1989, 102, 257-264. [CrossRef]

84. Rapp, R.; Shimizu, N.; Norman, M.; Applegate, G. Reaction between slab-derived melts and peridotite in the mantle wedge: Experimental constraints at $3.8 \mathrm{GPa}$. Chem. Geol. 1999, 160, 335-356. [CrossRef]

85. Wood, B.J.; Turner, S.P. Origin of primitive high-Mg andesite: Constraints from natural examples and experiments. Earth Planet. Sci. Lett. 2009, 283, 59-66. [CrossRef]

86. Zhang, Y.; Wang, Y.; Fan, W.; Zhang, A.; Ma, L. Geochronological and geochemical constraints on the metasomatised source for the Neoproterozoic ( 825Ma) high-mg volcanic rocks from the Cangshuipu area (Hunan Province) along the Jiangnan domain and their tectonic implications. Precambrian Res. 2012, 220-221, 139-157. [CrossRef]

87. Gao, S.; Rudnick, R.L.; Yuan, H.-L.; Liu, X.-M.; Liu, Y.-S.; Xu, W.-L.; Ling, W.-L.; Ayers, J.; Wang, X.-C.; Wang, Q.-H. Recycling lower continental crust in the North China craton. Nat. Cell Biol. 2004, 432, 892-897. [CrossRef] [PubMed]

88. Tatsumi, Y. Continental crust formation by crustal delamination in subduction zones and complementary accumulation of the enriched mantle I component in the mantle. Geochem. Geophys. Geosystems 2000, 1, 1. [CrossRef]

89. Wang, Q.; Li, Z.-X.; Chung, S.-L.; Wyman, D.A.; Sun, Y.-L.; Zhao, Z.-H.; Zhu, Y.-T.; Qiu, H.-N. Late Triassic high-Mg andesite/dacite suites from northern Hohxil, North Tibet: Geochronology, geochemical characteristics, petrogenetic processes and tectonic implications. Lithos 2011, 126, 54-67. [CrossRef]

90. Zeng, Y.-C.; Chen, J.-L.; Xu, J.; Wang, B.-D.; Huang, F. Sediment melting during subduction initiation: Geochronological and geochemical evidence from the Darutso high-Mg andesites within ophiolite melange, central Tibet. Geochem. Geophys. Geosyst. 2016, 17, 4859-4877. [CrossRef]

91. Hawkesworth, C.J.; Turner, S.P.; McDermott, F.; Peate, D.W.; Van Calsteren, P. U-Th Isotopes in Arc Magmas: Implications for Element Transfer from the Subducted Crust. Science 1997, 276, 551-555. [CrossRef]

92. Plank, T.; Langmuir, C.H. The chemical composition of subducting sediment and its consequences for the crust and mantle. Chem. Geol. 1998, 145, 325-394. [CrossRef]

93. Gao, Z.; Zhang, H.-F.; Yang, H.; Pan, F.-B.; Luo, B.-J.; Guo, L.; Xu, W.-C.; Tao, L.; Zhang, L.-Q.; Wu, J. Back-arc basin development: Constraints on geochronology and geochemistry of arc-like and OIB-like basalts in the Central Qilian block (Northwest China). Lithos 2018, 310-311, 255-268. [CrossRef]

94. Pearce, J.A. Geochemical fingerprinting of oceanic basalts with applications to ophiolite classification and the search for Archean oceanic crust. Lithos 2008, 100, 14-48. [CrossRef]

95. McKenzie, D.; O’Nions, R.K. Partial Melt Distributions from Inversion of Rare Earth Element Concentrations. J. Petrol. 1991, 32, 1021-1091. [CrossRef]

96. Aldanmaz, E.; Pearce, J.; Thirlwall, M.; Mitchell, J. Petrogenetic evolution of late Cenozoic, post-collision volcanism in western Anatolia, Turkey. J. Volcanol. Geotherm. Res. 2000, 102, 67-95. [CrossRef]

97. Wang, Y.; Zhang, A.; Fan, W.; Zhang, Y.; Zhang, Y. Origin of paleosubduction-modified mantle for Silurian gabbro in the Cathaysia Block: Geochronological and geochemical evidence. Lithos 2013, 160-161, 37-54. [CrossRef]

98. Guo, F.; Li, H.; Fan, W.; Li, J.; Zhao, L.; Huang, M.; Xu, W. Early Jurassic subduction of the Paleo-Pacific Ocean in NE China: Petrologic and geochemical evidence from the Tumen mafic intrusive complex. Lithos 2015, 224-225, 46-60. [CrossRef]

99. Chen, C.-H.; Lee, C.-Y.; Shinjo, R. Was there Jurassic paleo-Pacific subduction in South China?: Constraints from $40 \mathrm{Ar} / 39 \mathrm{Ar}$ dating, elemental and $\mathrm{Sr}-\mathrm{Nd}-\mathrm{Pb}$ isotopic geochemistry of the Mesozoic basalts. Lithos 2008, 106, 83-92. [CrossRef]

100. Yao, W.-H.; Li, Z.-X.; Li, W.-X.; Wang, X.-C.; Li, X.-H.; Yang, J.-H. Post-kinematic lithospheric delamination of the Wuyi-Yunkai orogen in South China: Evidence from ca. 435Ma high-Mg basalts. Lithos 2012, 154, 115-129. [CrossRef] 
101. Wang, Y.; He, H.; Gan, C.; Zhang, Y. Petrogenesis of the early Silurian Dashuang high-Mg basalt-andesite-dacite in eastern South China: Origin from a palaeosubduction-modified mantle. J. Geol. Soc. 2018, 175, 949-966. [CrossRef]

Publisher's Note: MDPI stays neutral with regard to jurisdictional claims in published maps and institutional affiliations.

(C) 2020 by the authors. Licensee MDPI, Basel, Switzerland. This article is an open access article distributed under the terms and conditions of the Creative Commons Attribution (CC BY) license (http://creativecommons.org/licenses/by/4.0/). 